Article No 240

DOI: https://doi.org/10.26881/srg.2020.7.15

Citation:

Yampolsky, M. (2020). Portret i ikona. Przeł. B. Żyłko. Studia Rossica Gedanensia, 7: 201-229.

DOI: https://doi.org/10.26881/srg.2020.7.15

\title{
PORTRET I IKONA ${ }^{1}$
}

\author{
MICHAIŁ JAMPOLSKI \\ New York University (United States) \\ Faculty of Arts \& Science \\ Department of Comparative Literature; Department of Russian and Slavic Studies \\ 19 University Place, 3 FL New York \\ New York (US), 10003 \\ E-mail:mi1@nyu.edu
}

\section{Przemienienie: pozór niemimetyczny}

Prawdopodobnie Rzym nie mógł zostać ukończony dlatego, że arabeskowy charakter jego konstrukcji, wyrażający energię signa translata, poetyki ucieleśnionego słowa, opierał się wszelkiej narracyjnej jedności. W Rzymie Nikołaj Gogol być może starał się przeprowadzić eksperyment, dotyczący obrazów niemimetycznych, ale eksperyment ten nie wyszedł poza początkowe próby. We wcześniejszym Portrecie rozwinął on krytykę mimetycznej reprezentacji, która przygotowywała późniejsze doświadczenia.

Wróćmy do fabularnej kanwy Portretu. Czartkow przynosi portret do domu i ten od razu poraża go swoim straszliwym spojrzeniem: „To już nie była sztuka. (...) To były żywe ludzkie oczy! Jakby wyjęte żywemu człowiekowi i tu wstawione. Nie ogar-

1 Tekst stanowi polski przekład dwóch fragmentów trzeciego rozdziału głośnej książki Michaiła Jampolskiego (Mihai Âmpol'skij) Tkač i vizioner. Očerki istorii reprezentacii, ili O material'nom i ideal'nom v kul'ture (Moskva: Novoe literaturnoe obozrenie, 2007 - oryg.: Михаил Ямпольский, Ткач и визионер. Очерки истории репрезентации, или О материальном и идеальном в культуре, Москва: Новое литературное обозрение, 2007). Rozdział nosi tytuł Портрет и икона. Autorem przekładu jest Bogusław Żyłko. [W niniejszej publikacji wyjątkowo stosuje się przypisy rzeczowe dolne (styl oksfordzki), zaś bibliografia załącznikowa zawiera tytuły transliterowane w systemie PN-ISO 9:2000 - przyp. Red.]. 
niała duszy wzniosła rozkosz, jakiej się doznaje patrząc na dzieło artysty”2. Ostateczne ożywanie portretu następuje nocą, kiedy światło księżyca pada na obraz. Czartkowa ogarnia uczucie nieprzezwyciężalnego lęku: „wyobraźnię i nerwy miał wrażliwe” - zauważa przy okazji Gogol. Czartkow kładzie się do łóżka, ale spojrzenie starca z portretu nadal go prześladuje; wówczas chwyta prześcieradło i owija w nie straszny obraz. Następnie zaczyna się „nadprzyrodzona” część narracji:

Blask księżyca potęgował białość prześcieradła i malarzowi zdawało się, że straszne oczy zaczęły przeświecać nawet przez płótno. Z przerażeniem wytężał wzrok, jakby chcąc się przekonać, że to absurd. Ale teraz już naprawdę... widzi, widzi wyraźnie: nie ma już prześcieradła... portret cały odkryty i patrzy poprzez wszystko, co ma na drodze, wprost na niego, zaziera mu prosto w samo wnętrze... Serce w nim zamarło. Widzi: starzec poruszył się i nagle oparł się obydwoma rękami o ramę. Uniósł się na rękach i wysunąwszy obydwie nogi wyskoczył z ram... ${ }^{3}$.

Wyjście z ramy parodystycznie odsyła do znakowego obrazu idealizującej tradycji - Madonny Sykstyńskiej ${ }^{4}$, gdzie, jak już mówiliśmy, rama została wykonana w technice trompe-l'oeil, która nadaje całemu płótnu Rafaela charakter teatralnego tableau. W dodatku cała sytuacja z Czartkowem odtwarza legendarną sytuację z Rafaelem ${ }^{5}$, która doskonale wpisuje się w strukturę przestrzeni Gogolowskiej, opisanej przez Jurija Łotmana. Rama i płótno przeciwstawiają się sobie jako różnorodne składniki, „komunikujące się" przy tym ze sobą. Gogol umieszcza ożywanie złowrogiego starca na obrazie we śnie, który z kolei zanurza się w następne sny ${ }^{6}$, reprodukując i nawet wzmacniając konstrukcję narracyjną Newskiego prospektu. Rafael wspominany jest w opowieści niejednokrotnie - po raz pierwszy, kiedy Gogol uważa za potrzebne uściślić, że Czartkow

2 M. Gogol, Opowieści. Przeł. J. Wyszomirski, J. Tuwim, J. Brzęczkowski. Oprac. B. Galster, Wrocław 1972, s. 96.

3 Tamże, s. 98.

4 Żukowski w słynnym „liście” o „Madonnie Sykstyńskiej” pisał: „W Bogurodzicy, kroczącej po niebiosach, nie widać żadnego ruchu; ale im dłużej patrzymy na nią, tym bardziej wydaje się nam, że ona się zbliża” (B.A. Жуковский, Rафаелева „Мадонна”. W: В.А. Жуковский, Эстетика и критика, Москва 1985, s. 309-310).

5 Mit Wackenrodera o Rafaelu zyskał w Rosji wielką popularność. Liczne rosyjskie przeróbki tego mitu zostały przeanalizowane w pracy: Р.Ю. Данилевский, Заметки о темах западноевропейской живописи в русской литературе. W: Русская литература и зарубежное искусство, Ленинград 1986, s. 281-298.

6 Przytoczę elementy tej ramy, do której włączone jest opowiadanie: „ «Czyżby to był sen?» — powiedział ujmując głowę w obydwie ręce, ale przerażająca żywość zjawiska nie była podobna do snu. Już po przebudzeniu widział, jak starzec wszedł w ramy”. Po chwili wyjaśniło się, że przebudzenie było też snem. „A więc to nie był sen, rysy starca drgnęły, a wargi poczęły się wyciągać ku niemu, jakby chcąc wyssać z niego krew... Z krzykiem rozpaczy odskoczył - i znowu się obudził”.

«Czyżby i to był sen?» - Z bijącym sercem, które nieomal gotowe było pęknąć, pomacał rękami dokoła siebie. Tak, leży w łóżku w tej samej pozycji, w jakiej zasnął. Ale wkrótce rama znowu się pojawia: „«Boże, co to jest! - zawołał żegnając się z rozpaczą i obudził się!».

To był także sen! Zerwał się z łóżka na pół przytomny, oszołomiony: w żaden sposób nie mógł sobie wytłumaczyć, co się z nim dzieje: koszmar czy duchy, gorączkowe bredzenie czy żywe widziadło?" (M. Gogol, Opowieści, s. 99-100). Podobna konstrukcja ramowa, oparta na nierozróżnianiu snu i realności, prawdopodobnie była rozważana także w Nosie, z której pozostały tylko ślady. 
"nie rozumiał jeszcze całej głębi Rafaela" . Arabeska demonicznego ruchu zostaje tu całkowicie skorelowana $\mathrm{z}$ arabeską boskiego ruchu, powiązanego z madonną Rafaela.

Ale oczywiście motyw ożywienia, kojarzony z Galateą czy Madonną Sykstyńską, został przeniesiony tutaj do całkowicie nieidealnego kontekstu i połączony z apokaliptycznym motywem wskrzeszenia, ożywienia Antychrysta. To ożywienie Antychrysta samo w sobie jest już parodią tej metamorfozy, jakiej podległo ciało Chrystusa po jego śmierci i które jest już zapowiadane w Przemienieniu na świętej górze ${ }^{8}$. I tutaj znów pojawia się imię Rafaela, tym razem w kontekście „Przemienienia”, o którym była już mowa i które, jak wiemy, figuruje w Gogolowskim Testamencie. Przemienienie (transfiguracja) jest radykalną transformacją ciała. U Łukasza zjawisko to zostało opisane następująco: „(...) i wyszedł na górę, aby się pomodlić. Gdy się modlił, wygląd Jego twarzy się odmienił, a Jego odzienie stało się lśniąco białe” (Łk 9, 28-29). Przy tym Łukasz dodaje szczegół, który Gogol intensywnie rozbudowuje: „Tymczasem Piotr i towarzysze snem byli zmorzeni. Gdy się ocknęli, ujrzeli Jego chwałę..." (Łk 9, 32). Przemienienie początkowo jawi się apostołom jakby poprzez zasłonę snu. Mateusz tak opowiada o tym zdarzeniu: „Tam przemienił się wobec nich: twarz Jego zajaśniała jak słońce, odzienie zaś stało się białe jak światło” (Mt 17, 2). A oto wersja Marka: „Jego odzienie stało się lśniąco białe, tak jak żaden na ziemi folusznik wybielić nie zdoła" $(9,3)$.

Jaskrawy blask księżyca ${ }^{9}$, białość prześcieradła, transformacja portretu - wszystko to jest jawną parodią transfiguracji ${ }^{10}$. W ewangelijnym przemienieniu następuje ujawnienie nadsubstancjalności Chrystusa, który ukazuje swoją prawdziwą naturę czystego boskiego światła. Sens transfiguracji zawiera się w tym, że materialne ciało i twarz Chrystusa ujawniają swoją nieprawdziwość, jawią się jako „figura”, za którą powstaje coś innego. Poczynając od Tertuliana, tradycja chrześcijańska pojmuje pewne postacie historyczne jako prefigurację czegoś innego ${ }^{11}$. Sens figury tkwi w tym, że odsyła do czegoś poza sobą. W Przemienieniu figura ciała odsyła do boskiego światła.

\footnotetext{
7 Tamże, s. 92.

8 Tradycja zazwyczaj uważa tę górę za górę Tabor, co historycznie nie jest możliwe, gdyż na jej stosunkowo niewysokim szczycie znajdowała się twierdza.

9 Michaił Wajskopf w księżycowym świetle dostrzega gnostyczny motyw demonicznego przywłaszczenia światła (М. Вайскопф, Сюжет Гоголя, Москва 2002, s. 386).

10 Jak wykazały badania Wajskopfa, Gogol parodiował nie tylko Przemienienie, ale również misterium Eucharystii. Parodia ta, zdaniem Wajskopfa, zawiera się w fabule Nosa, którego akcja także rozwija się 25 marca - w dzień Zwiastowania (М. Вайскопф, Нос в казанском соборе: о генезисе религиозной темы. W: М. Вайскопф, Прица-тройка и колесница дуии, Москва 2003, s. 164-185). Odkrycie nosa w chlebie rzeczywiście może być łatwo odczytywane jako parodia przeistoczenia ciała Chrystusa w prosforze. Ta para parodii jest ciekawa ze względu na swoją komplementarność. Jeżeli parodia Przemieniania kojarzy transfigurację z czystą mimetyczną iluzją, to w Nosie - odwrotnie - mowa jest o całkowitym braku czegoś symbolicznie reprezentatywnego, by tak rzec, o tępej materialności. Ciało (nos) bezpośrednio jest zapieczone w chlebie. Oba warianty są odrzucane przez Gogola jako nieodpowiadające poziomowi jego zadań. Gogol nie chce ani prostej materialności, ani iluzorycznej pozorności.

11 E. Auerbach, „Figura”. W: E. Auerbach, Scenes from the Drama of European Literature, New York 1959, s. 28ff. „Prefigurację” nie powinno się mieszać z „typologią”. Odnosi się ona nie tyle do porządku powtórzenia, co proroctwa.
} 
Ale właśnie to nadaje całej scenie Przemienienia dość wątpliwy z punktu widzenia dogmatu chrześcijańskiego charakter. Norman Brown nazywa epizod Przemienienia „nieusuwalnym doketycznym momentem w naszych kanonicznych Ewangeliach”12. Doketyzm to błąd dogmatyczny, nawet herezja, która sprowadzała się do negowania materialnej realności ciała Chrystusa. Zgodnie z takimi wyobrażeniami Chrystus nie miał ciała materialnego, ale jedynie pozorność ciała, fantazmat ciała (sam termin utwo-

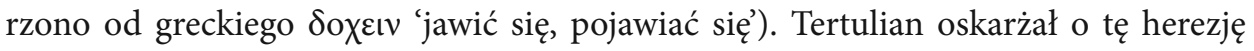
Marcjana i wskazywał, że doketyzm w ostatecznym rachunku prowadzi do odrzucenia dogmatu zmartwychwstania ciała ${ }^{13}$. Friedrich Schleiermacher wykazał, że dogmatyka doketów bezpośrednio wiąże się z problematyką pozorności, która właściwie interesuje mnie tutaj:

Jeśli różnica pomiędzy Chrystusem a tymi, kto potrzebuje wskrzeszenia, staje się tak nieskończona, że istotnościowe podobieństwo okazuje się nie do pogodzenia z nią, to Jego uczestnictwo w ludzkiej naturze znika w zwykłej pozorności i, co za tym idzie, nasza świadomość Boga, będąc istotnościowo różna, nie może wywodzić się z Jego [świadomości], a odkupienie również okazuje się tylko pozornością. Teraz, choć dokeci, słusznie tak nazywający się, wprost negowali tylko realność ciała Chrystusa, tym samym jednak wykluczano również ludzką naturę jego Postaci w ogóle, gdyż nigdy nie stykamy się z ciałem i duszą, danymi oddzielnie... ${ }^{14}$.

Przemienienie jest centralnym zdarzeniem dla doketyzmu dlatego, że w nim ujawnia się nieludzka, świetlna natura Chrystusa. Innymi słowy, ciało Chrystusa jest czystą iluzją, podobnie jak i związane z nim wskrzeszenie zmarłych. Cała misja Chrystusa w rezultacie okazuje się czystą pozornością. Gogol parodiuje Przemienienie właśnie w doketycznym kluczu: to, co wydaje się nam życiem, realnością, stwarzaną przez imitację w portrecie jest niczym więcej jak demoniczną iluzją.

Problematyka Przemienienia odegrała ważną rolę w prawosławiu, w ramach którego rozwinął się cały kierunek, powiązany z teologią światła Taboru. Legł on u podstaw hezychazmu (Symeon Nowy Teolog, Grzegorz Synaita, Grzegorz Palamas i in.), dla którego problem Przeobrażenia jest jednym z centralnych problemów. W głównym ośrodku hezychazmu na górze Athos, poczynając mniej więcej od 1000 roku, mnisi pragnęli ujrzeć światło Taboru, w którym dla nich zawierała się prawdziwa teofania Chrystusa ${ }^{15}$. Ruch ten zapuścił korzenie w nauce Pseudo-Dionizego Areopagity, wzy-

12 N.O. Brown, Apocalypse and/or Metamorphosis, Berkeley 1991, s. 557.

13 On zaś dotykał również przemienienia jako widzialnej substancjalnej zmiany ciała: „Ma się rozumieć, prawo natury tego, co się zmienia jest takie, że nie przebywa ono w tym, co się zmienia, a ponieważ nie przebywa, to ginie, jeśli wskutek zmiany traci poprzedni swój byt. Ale nic nie równa się Bogu: Jego natura różni się od stworzoności wszystkich rzeczy. Zatem, jeśli wszystko różniące się od Boga lub to, od czego On się różni, zmieniając się, przestaje być, czym było, to w czymże tkwi odrębność Bóstwa od innych rzeczy, jak nie w przeciwstawnej [właściwości]: to jest w zdolności Boga do przemieniania się we wszystko i zarazem do pozostawania takim, jakim On jest?" (Тертуллиан, Избранные прозиведения, Москва 1994, s. 163).

14 F. Schleiermacher et al., The Christian Faith. Vol. 1, New York-Evanston 1963, s. 99.

15 Zob. M. Pulver, The Experience of Light in the Gospel of St. John, in the "Corpus hermeticum”, in Gnosticism, and in the Eastern Church. W: Spiritual Disciplines. Papers from the Eranos Yearbooks. Ed. by J. Campbell, Princeton, N.Y., 1960, s. 239-266. 
wającego do wzniesienia się ponad ziemskie sprawy i kontemplowania Boga $\mathrm{w}$ „Nadnaturalnym Promieniu, w którym wszystkie rodzaje wiedzy mają swoje naturalne granice..." ${ }^{16}$.

Światło Taboru stało się przedmiotem zaciekłych dyskusji, dotyczących natury tego światła. Sami hezychaści mówili o tym świetle jako energii (energeia) Boga, która różni się od istoty (ousia). Przy tym światło zyskiwało znaczenie czegoś niestworzonego i do końca niepojętego. Grzegorz Palamas pisał o tym świetle chwały jako o właściwej chwale bożej ${ }^{17}$. Rozróżnienie to było ważne, gdyż oddalało oskarżenie o to, że święci ojcowie na górze Athos biorą pozorność za przejaw Boga. Oto jak opisywał Pawieł Fłorenski argumenty przeciwnika hezychastów Barlaama z Kalabrii:

Barlaam twierdził, że albo pokutnikom jawi się coś stworzonego, a zatem niewykraczające poza granice stworzenia, a więc halucynacyjne $\mathrm{w}$ stosunku do Boga, albo też komunikują się oni z samą istotą Boga. Ale ponieważ zjednoczenie stworzenia i Twórcy jest niemożliwe, zatem pozostaje pierwsze stwierdzenie, czyli że oni się oszukują względem natury widzianego przez nich światła ${ }^{18}$.

Właśnie tutaj nabrał mocy opracowany przez Grzegorza Palamasa argument o tym, że Bóg oprócz istoty posiada jeszcze energię - „działalność, samoujawnianie się”, którą można ujrzeć jako promień z góry Tabor. Teologia hezychazmu była zakorzeniona w neoplatońskiej tradycji mistycznej, zgodnie z którą jesteśmy w stanie pojąć jedynie to, co jest pokrewne nam i dlatego możemy dotrzeć do Boga jedynie wtedy, kiedy sami się oczyścimy i zaczniemy „uczestniczyć” w boskiej naturze. Tylko oczyszczony umysł świętego może zobaczyć Boga jako odbicie światła własnej duszy. W jakimś sensie chodziło o to, o czym była już mowa wcześniej w związku z modlitwą i słowem bożym, które staje się dostępne poprzez modlitwę, przynależną już samo przez się do Boskiego logosu. Hezychastyczna wersja jest interesująca przez to, że jest antymimetyczna i również opiera się na zasadzie podobieństwa widzialnego do zdolności widzenia, tak samo jak i teologia inkarnacji. Grzegorz Palamas pisał:

Rzeczywiście, światło daje się zobaczyć w świetle i w podobnym świetle - widzące; jeśli nie ma żadnego innego działania, to widzące, abstrahując od wszystkiego innego, samo staje się całkowicie światłem i upodabnia się do widzialnego, a raczej bez mieszania się jednoczy się z nim, będąc światłem i widząc światło za pośrednictwem światła: czy spojrzy na siebie - widzi światło; czy spojrzy na to, co widzi - ciągle to samo światło; czy na to, poprzez co widzi - światło jest i tutaj; i jednoczenie w tym, żeby to wszystko było jednym, tak żeby widzący nie mógł już rozpoznać, ani

16 Dionysius the Areopagite, On the Divine Names and the Mystical Theology, London-New York 1940, s. 58

17 Henry Corbin wykazał, że motyw światła chwały w zarodkowej postaci pojawia się w zoroastryzmie i mazdaizmie. Chwała (Aura Gloriae, flammula, Orie-flambe) jest atrybutem świętych figur w Aweście. Właśnie ze Wschodu przenosi się ona na figury Chrystusa i na świętych na Zachodzie oraz na Buddy i bodhisattwy na Wschodzie. Również we wschodniej teozofii zdaniem Corbina światło po raz pierwszy przestaje być pojmowane jako obiekt widzenia, lecz jako „to, co umożliwia widzenie”. Wreszcie Corbin przytacza niezwykle ciekawe fakty o tym, w jaki sposób Światło Chwały (doxa) zaczyna kojarzyć się z istnieniem i osobistym losem (tykhè). Zob. H. Corbin, En Islam Iranien. Sohrawardî et les Platoniciens de Perse. Vol. 2, Paris 1971, s. 81-86.

18 П.А. Флоренский, У водоразделов мысли. Т. 2, Москва 1990, s. 327. 
to, czym on widzi, ani to, na co patrzy, ani to, czym to jest, oprócz tylko tego, ze stał się światłem i widzi światło, różne od wszelkiego stworzenia ${ }^{19}$.

To widzenie umysłu w umyśle różni się od wiedzy i nosi apofatyczny charakter. Sama zaś zazwyczaj refleksyjna forma widzenia tutaj jest całkowicie antyreprezentatywna, ponieważ zupełnie znosi różnicę pomiędzy podmiotem i przedmiotem, modelem i jego obrazem. Przy tym autokontemplacja widzenia jako widzenia światła tutaj nie ma wymiaru zmysłowo-mimetycznego. Widzenie nie kopiuje świata, ale czyni niewidzialne (niecielesne) widzialnym. Carl Havelange tłumaczy, że „efektywność spojrzenia” zawiera się w jego zdolności do „obdarzania ciałem tego, co jest niewidzialne”. Spojrzenie realizuje spotkanie, które tworzy obecność. Jeśli dwoje ludzi widzi się nawzajem, to ich spojrzenia tworzą sytuację wzajemnej obecności:

(...) świadek obecności, [spojrzenie] pozwala istnieć; innymi słowy, łączy ze światem i oddziela od niego. Można powiedzieć, że w tej operacji «widzialność widzenia» odróżnia - tworzy ona współobecność dwóch różnych istot (entité séparées) - i że jego niewidzialność łączy: część niewidzialnego, niosąca widzialność, zawsze zyskuje siłę związku. To tak jakby - jeśli chcieć to wyrazić innymi słowami - akt widzenia był nierozerwalnie związany z widzeniem (widzialnym) i intencja (niewidzialnym) ${ }^{20}$.

William Ralph Inge w swojej klasycznej pracy o chrześcijańskim mistycyzmie pisze, że zadaniem takiej kontemplacji jest kontakt $\mathrm{z}$ absolutnie niezróżnicowanym i ponadbytowym Absolutem. Przy tym wszelki element zmysłowego w odbiorze Absolutu nieodwracalnie pozbawia go absolutności. Sama ta „absolutność” nie jest trwała. Grzegorz Palamas zauważa: „(...) kontemplacja światła jest jednoczeniem, chociaż jest ono nietrwała u profanów; a cóż takiego jednoczenie ze światłem, jak nie widzenie?" ${ }^{21}$. Trudno wyobrazić sobie obiekt takiego widzenia, i nie mniej trudno jest wyobrazić widzenie bez obiektu. Inge pisze:

W rzeczywistości percypuje się nie Absolut, ale pewną «nieforemną formę», ideę nie Nieskończoności, lecz Nieokreśloności. W ten sposób staje się niemożliwe odróżnić Jedno, o którym mówi się, że jest ono ponad wszystkimi różnicami, od niezróżnicowanej materii, pozbawionej formy Ni-cości (No-thing), którą Plotyn umieszcza na dolnym stopniu swojej drabiny ${ }^{22}$.

Plotyn identyfikował zło z Nie-bytem, czyli właśnie z Ni-cością Inge’a. Przy tym niebyt zła nie oznacza u niego nieistnienia, lecz radykalną odrębność od Autentycznego Bytu $^{23}$. Kontemplujący Absolut zawsze ryzykuje pomylenie stworzonego, materialne-

19 Св. Григорий Палама, Триады в защиту священно-безмолвствующих. Пер. на рус. язык В. Вениаминовым, Москва 1995, s. 223.

20 C. Havelange, De l'oeil et du monde, une histoire du regard au seuil de la modernité, Paris 1998, s. 196.

21 Св. Григорий Палама, Триады в защиту священно-безмолвствующих..., s. 223.

22 W.R. Inge, Christian Mysticism, New York 1956, s. 98.

23 „Nieistniejące zaś jest to nie w ogóle nieistniejące, ale tylko coś innego niż istniejące (byt). Przy czym nie jest ono bytem nie w taki sposób, w jaki ruch i bezruch nie są samym bytem, lecz jak podobieństwo bytu, lub być może czymś nawet w jeszcze większym stopniu nieistniejącym [niż podobieństwo]. A właśnie takie jest wszystko, co zmysłowe i wszystkie stany zmysłowości; dalej, takie są 
go z absolutnym. Niezróżnicowanie i nieokreśloność w zasadzie nie dają się odróżnić od absolutnie ponadbytowego. Nie można z pewnością powiedzieć, że, kontemplując samo widzenie, kontemplujemy Boga, a nie materialny warunek naszej umiejętności widzenia. Problem ten stanął przed wszystkimi mistykami typu wizjonerskiego.

Hezychastyczna interpretacja Przemienienia koresponduje z problematyką wyobraźni. Wyobraźnia, wznosząc się od materialnego do pojmowanego umysłem, zawsze staje przed groźbą zobaczenia tylko widma materialności, jedynie złudzenia realności. W szerszym planie chodzi o nierozróżnianie materialności i idealności.

Kiedy zaczyna się mówić o Przemienieniu, zazwyczaj pojawia się system radykalnych opozycji, których niewystarczalność od razu daje o sobie znać. Tak oto Przemienienie od samego początku natykało się na problem stworzoności w opozycji do boskiej niestworzoności. Negowanie cielesności Chrystusa oznacza negowanie możliwości obecności boskiej substancji w jego stworzeniu. Jak mawiał Barlaam: „połączenie stworzenia i Stwórcy jest niemożliwe”. Stwórca jest transcendentny w stosunku do swojego stworzenia.

Właśnie w tym kontekście szczególnie ciekawy staje się ten radykalny wariant rozwiązania problemu trudności rozróżnienia czegoś pozbawionego formy i absolutu, który pozwala przezwyciężyć binarność opozycji, binarność istot w zdarzeniu Przemienienia. W apokryficznych Dziejach Piotra, niezwykle popularnych wśród gnostyków i manichejczyków, opowiada się o Przemienieniu na górze Tabor. Piotr mówi o przemienionym Chrystusie w sposób bardzo nieokreślony: „Każdy z nas zgodnie z tym widzeniem, które mógł przyjąć, zobaczył to, do czego był zdolny" $(20)^{24}$. Nie wierzy Piotrowi kilka wdów, wśród których są osoby ślepe. Wówczas apostoł wzywa obecnych, by się modlili i postarali się zobaczyć scenę nie oczami, lecz wzrokiem wewnętrznym: „odbierajcie w umyśle to, co widzicie nie oczami waszymi i choć oczy wasze są zamknięte, dajcie im otworzyć się wewnątrz was" $(21)^{25}$. Modlitwa wywołuje w pomieszczeniu strumienie "niewidzialnego światła”, które nie może być opisane przez człowieka. Niewidzialne światło wpada do oczu kobiet, nadal stojących pośród leżących na ziemi ludzi. Kiedy je pytają, co widziały, okazuje się, że jedne widziały „starca, takiej dobroci, że nie sposób to wyrazić, ale inne powiedziały: widziałyśmy młodzieńca, a jeszcze inne: widziałyśmy chłopca, ostrożnie dotykającego nasze oczy"

wszystkie przypadkowe właściwości rzeczy zmysłowych; taki jest pierwiastek zmysłowego; taka jest każda oddzielna część składowa z wypełniających zmysłowy [świat rzeczy].

Już teraz można sobie stworzyć [ogólne] wyobrażenie o [nie-bycie]: [w stosunku do bytu] jest on bezmiarem w stosunku do miary; jak bezkres do kresu; jak bezrodzajowe w stosunku do rodzajotwórczego; jak zawsze potrzebującego w stosunku do samowystarczalnego; jest on zawsze nieokreślonym, całkowicie niestabilnym, niepercypowanym, nienasyconym, kompletne ubóstwo. I wszystko to nie są jego przypadkowe właściwości, lecz jakby jego sama istota; tak że jakąkolwiek część jego my byśmy nie rozpatrzyli, w niej wszystko to będzie. A inne rzeczy - te, które okazują się mu [nie-bytowi] przynależne albo upodobniają się do niego, stają się złe, jednakże nie są złe [w swojej istocie]", 1, 8, 3 (Плотин, Сочинения, Санкт-Петербург 1995, s. 592).

24 The Acts of Peter. W: The Apocryphal New Testament: a collection of apocryphal Christian literature in an English translation. Ed. by J.K. Elliot, Oxford-New York 1993, s. 413.

25 Tamże, s. 414. 
$(21)^{26}$. Każda miała widzenie odpowiadające jego właściwościom. Każda, w całkowitej zgodzie z szacowną tradycją wizjonerskiego mistycyzmu, widziała to, co było dane zobaczyć. Historia ta koresponduje z wyobrażeniem Gogola o różnorodności ludzkich możliwości przejawiania siebie w świetle bożego słowa: modlitwy.

Henry Corbin w tym fragmencie Dziejów Piotra dostrzega odpowiednik tego, co w sufizmie Ibn Arabiego nazwał on „twórczą wyobraźnią”. Corbin wyjaśnia, że podstawowa idea mistycznej teozofii Ibn Arabiego i zbieżnych z nią teozofii zawiera się $\mathrm{w}$ tym, że Stworzenie u swoich podstaw jest teofanią. Stworzenie jest produktem boskiej wyobraźni, zaś twórcza wyobraźnia ze swej natury jest teofaniczna Wyobraźnią. Aktywna wyobraźnia gnostyków jest również teofaniczną wyobraźnią. Bóg, stwarzany przez człowieka, nie jest zwykłym produktem swobodnej fantazji, lecz teofanią; aktywna wyobraźnia człowieka nie jest niczym innym jak organem absolutnej teofanicznej wyobraźni ${ }^{27}$. Innymi słowy, to, co wyobraża sobie człowiek, jest formą przejawu Boga w nim. Ale to oznacza, że wizja, fantom nie jest po prostu fałszywą halucynacją, jak sądził Barlaam, lecz realnością Boga ${ }^{28}$. Rozwiązanie to wykracza daleko poza granice mimetycznej reprezentacji. Widzenie (w tym także i to na górze Tabor) przestaje być pozornością, fałszem, iluzją, reprezentacyjnym mirażem. Przestaje ono być w istocie właściwym obiektem widzenia, lecz staje się nieodłączne od aktu, zdarzenia patrzenia, tak jak wypowiedź w modlitwie miesza się z aktem wypowiedzi.

Jacques Delille w swoim poemacie Wyobraźnia, o którym wspominałem w związku z Batiuszkowem, przytacza przykład potraktowania wyobraźni artystycznej jako teofanicznej. Znamienne, że wykorzystuje on dla swoich rozważań klasyczny model - Przemienienie Rafaela.

Mais du monde réel franchissant la barrière,

Dans le monde ideal s'il étend carrére,

Comment montrer à l'homme un objet plus qu'humain,

Peindre un être immortel d'une mortelle main,

Lui composer des sens, une forme, un visage,

Et créer à la fois le modèle et l'image?

C’est la que du génie épuisant les secrets,

L'imagination épure tous ses traits;

Là, triomphe son art. C'est toi que jen atteste,

O divin Raphaël, dont le pince au céleste

Osa représenter, par un sublime essor,

Le Christ transfiguré sur le Mont de Thabor.

Ah! Pour ce grand moment où, reprenant son être,

Le dieu va se monter et l'homme disparaitre,

Où prendre ton modèle, artiste audacieux?

26 Tamże, s. 415.

27 H. Corbin, Creative Imagination in the Sufism of Ibn Arabi. Transl. by R. Manheim, Princeton 1969, s. $182-183$.

28 N.O. Brown wskazuje na to, że spekulacje Ibn Arabiego są zbieżne z wyobrażeniami Coleridge’a o pierwotnej wyobraźni, która z jednej strony odpowiada za odbiór, z drugiej zaś jest „powtórzeniem w ostatecznej świadomości wiecznego aktu stworzenia w nieskończoności” (N.O. Brown, Apocalypse and/or Metamorphosis..., s. 67). 
Il n'est point sur la terre, il n'est point dans les cieux;

Il est dans la pensée. Il des sine, il colore,

Il dit: „Que le dieu nassie”, et le dieu vent déclore!...29.

[Przekraczając granice realnego świata, / Rozprzestrzeniając się na realny świat, / Jak może ona ukazać człowiekowi bardziej niźli ludzki obiekt, / Namalować nieśmiertelną istotę śmiertelną ręką,/ Nadać mu swemu uczuciu formę, twarz, / I jednocześnie stworzyć i wzór, i obraz? / Właśnie w takim wypadku, wykorzystując wszystkie sekrety geniuszu, / Wyobraźnia oczyszcza wszystkie jego cechy; / Właśnie wówczas następuje triumf sztuki, Ciebie wzywam na świadka, / Boski Rafaelu, którego niebiański pędzel / Ośmieliła się przedstawić we wzniosłym porywie / Przemienionego Chrystusa na górze Tabor, / O! Gdzie dla tego wielkiego momentu, kiedy, odtwarzając swoją istotę, / Bóg objawi siebie, a człowiek zniknie, / Gdzie znaleźć dla niego wzorzec, nieustraszony artysto? / Jego nie ma na ziemi, ale nie ma go i w niebie;/ Jest on w myśli, on maluje, koloruje, / Mówi: „Niech stanie się bóg!”, i bóg się staje!..]

Delille podkreśla podobieństwo twórczej i boskiej wyobraźni. Osobliwość pracy Rafaela nad Przemienieniem zawiera się w nieprzekładalności zasad naśladowania. Malarz nie dysponuje po prostu modelem do naśladowania. Zablokowanie mimesis otwiera drogę twórczej wyobraźni, które jednocześnie okazuje się manifestacją Boga. Artysta tworzy Boga w swoim wewnętrznym widzeniu, naśladując boski akt tworzenia. Ale $\mathrm{w}$ tym paradoksalnym geście stworzenia ciało przeobraża się $\mathrm{w}$ osiągalny umysłem absolut, który utracił materialność. Dlatego produkt jest tutaj tożsamy boskiemu Słowu, które nie posiada materialności i tworzy się abstrakcyjnie w umyśle Boga. Zamiast tego, żeby być stworzonym, stworzenie okazuje się niematerialne. Już w tej sytuacji rozróżnienie stworzonego i niestworzonego okazuje się częściowo skompromitowane, podobnie jak rozróżnienie pomiędzy modelem i jego obrazem. Właśnie $\mathrm{w}$ tej formie teofanicznej wyobraźni ujawnia się Zwiastowanie. Ale mimo wszystko Delille nie może do końca porzucić opozycji wzorca i kopii, czyli opozycji, na której ufundowany jest platoniczny mimetyzm i reprezentacja. Artysta jednocześnie wytwarza oryginał i kopię; przy tym oryginał i kopia okazują się w stanie nieodróżnialności dlatego, że obie te rzeczy istnieją w umyśle, ale również dlatego, że stworzony obraz Boga, nie będąc kopią, występuje w charakterze oryginału.

U Gogola wszystko jakby zaczyna się tak samo, ale dzieje się całkowicie odwrotnie. Przemienienie jest u niego parodystyczne dlatego, że pojmuje się je w nurcie Barlaama, a nie hezychastów. Przemienienie nabytego przez Czartkowa portretu jawi się nie jako radykalne przezwyciężenie mimetyzmu, ale jako mimetyzm, doprowadzony do ekstremu, poza którym zaczyna się demoniczna magia ożywania kopii. Metamorfoza portretu lichwiarza jakby imituje Przemienienie Pańskie, ale już z powodu tylko tego naśladowczego impulsu okazuje się ono nieprawdziwe. Rozwija się nie w płaszczyźnie chrześcijańskiej oikonomii, opartej na zasadzie „niepodobnego podobieństwa”, lecz w płaszczyźnie czysto „magicznej”, „demonicznej”, maksymalnej imitacji eidolonu. Portret ten podobny jest do sztucznej figury Pandory - tego ucieleśnienia katastroficznego oszustwa.

Ciekawe jest porównanie w związku z tym Portretu z jednym z jego możliwych źródeł - Diabelskimi eliksirami E.T.A. Hoffmanna. U Hoffmanna ekwiwalentem hi-

29 Oeuvres de J. Delille. T. 8-9: L'imagination II, Paris 1824, s. 9. 
storii Czartkowa jest historia malarza Francesco, ucznia Leonardo. Francesco jest fanatycznym wielbicielem antycznego pogaństwa i rozkoszy cielesnych. Szczególną namiętność żywi on wobec „słynnego posągu Wenery”. Pewnego razu kapucyni zamawiają u niego obraz świętej Rozalii. „Miał zamiar przedstawić świętą zupełnie nagą i uczynić ją w kształtach i rysach twarzy zupełnie podobną do ubóstwianego posągu Wenery"30. Ale w miarę malowania obrazu zaczęła się ona zmieniać i demonstrować swoją władzę nad artystą, który wbrew swoim chęciom przykrywa jej obnażone ciało ubraniem. Jednakże nie jest on w stanie namalować jej twarzy. Maluje jej oblicze, nadając jej maksymalne podobieństwo do Wenery. W tym momencie następuje właśnie ożywanie obrazu (motyw wykorzystany przez Gogola):

A przecież anielskie oblicze świętej wyłaniało się coraz widoczniej na światło z osłony cieniów i spojrzało nagle na Francesco oczami tak pełnymi promiennego życia, że runął na ziemię, jak śmiertelnie rażony piorunem. Gdy znowu przyszedł do przytomności i opanował się nieco, podniósł się z ziemi i nie patrząc na obraz, napełniający go trwogą, podszedł do stołu ${ }^{31}$.

Hoffmann gra tutaj przeciwstawnością dwóch połączonych w osobie świętej Rozalii pierwiastków. Z jednej strony obraz charakteryzuje się jako „niemy”, z drugiej zaś strony patrzy na malarza „żywymi oczami”. Ta kombinacja niedających się połączyć pierwiastków być może powoduje omdlenie Francesca.

Z płótna spogląda na niego Wenera, wywołująca w nim ziemskie pożądanie, przypominające uczucie Pigmaliona żywione do Galatei. Francesco błaga Wenerę, by ta tchnęła życie w obraz. „Wkrótce poczęło mu się zdawać, że obraz zaczyna się ruszać, lecz gdy go chciał ująć w ramiona, ujrzał, że ma przed sobą tylko martwe płótno"32. Po pewnym czasie Francesca odwiedza młoda kobieta, „w której poznał oryginał swojego obrazu". Francesco łączy się z nią w pogańskim związku i żyje w grzechu, dopóki nie urodzi mu syna. Ale od razu po porodzie kobieta umiera i ciało jej nieoczekiwanie ulega metamorfozie: „(...) szyję i piersi pokryły sine, obrzydliwe plamy, a zamiast młodego, pięknego oblicza ujrzeli szeroko rozwarte oczy i szpetnie zniszczone, pomarszczone oblicze” ${ }^{33}$. Wyjaśnia się, że kobieta zawarła pakt z diabłem, zaś ,jej piękność była tylko łudzącym wytworem przeklętego czarnoksięstwa" ${ }^{34}$.

Tok myśli Hoffmanna jest bliski Gogolowskiemu, choć oczywiście nie jest z nim identyczny. U Hoffmanna sztuka, jeśli nie prowadzi do absolutu, ześlizguje się w sferę czystej pozorności i materialności, która rozpada się, ujawniając bezkształt nieuduchowionej i nieuformowanej materii. Sztuka tego rodzaju produkuje czyste symulakry. Ale u Hoffmanna nie ma nawet śladu motywu przemienienia i światła. Gogol jest bardziej skomplikowany niż Hoffmann. U niego wyobraźnia porusza się w stro-

30 E.T.A. Hoffmann, Diable eliksiry. Przeł. L. Emirowicz, Warszawa 1958, s. 296.

31 Tamże, s. 229-300. Ciekawe, że taką samą reakcję wywołuje w apokryficznym Objawieniu Piotra Przemienienie: „zobaczywszy ich [przemienionych «braci naszych, którzy odeszli ze świata»], przeraziliśmy się, gdyż ich ciała były bielsze od wszelkiego śniegu i czerwieńsze od wszelkiej róży”. Albo: „Ujrzawszy ich piękno, przestraszyliśmy się go, kiedy nagle zjawili się oni” (Апокрибические Апокалипсисы, Санкт-Петербург 2001, s. 197.

32 Tamże, s. 300.

33 Tamże, s. s. 302.

34 Tamże, s. 302. 
nę przemienienia, które nieoczekiwanie obraca się w swoje przeciwieństwo. Im dalej idzie wyobraźnia, tym bliżej podchodzi do swojej „granicy”, poza którą możliwa jest albo nieprawdopodobna paradoksalność ucieleśnionego słowa, albo pseudoprzemienienie, którego sens całkowicie wyczerpuje się w doketycznej pozorności. W jednym wypadku następuje niepojęte połączenie dwóch natur i ciało zmartwychwstaje, przy czym różnica między oryginałem i kopią znika. W drugim wypadku oryginał ujawnia swoją przemijalność poprzez pseudozmartwychwstanie w kopii. Ale oryginał okazuje się zdecydowanie odmienny od obrazu, jawiąc się w postaci szkaradnego trupa lub demona. Delille’a tworzenie obrazu i kopii jest tu jednocześnie nieoczekiwanie wywrócone na opak - od kopii wyobraźnia kieruje się ku oryginałowi, który nagle pojawia się w całej swojej straszliwej stworzoności. Mowa o desublimacji twórczości. Mamy przed sobą nie Pigmaliona, rozpłomienionego Galateą, ale artystę, z przerażeniem odkrywającego, że Galatea ożyła, przestała być wzorcem, następnie zmarła i nabrała obrzydliwych cech trupa.

\section{Weronika i portret}

W podtekście epizodu z ożywającym portretem u Gogola znajduje się nie tylko Przemienienie, ale jeszcze jeden ważny motyw chrześcijańskiej ikonografii, a mianowicie motyw Weroniki, odbicie twarzy Chrystusa na chuście św. Weroniki ${ }^{35}$. Chusta Weroniki jest względnie późną wersją (XIII w.) nie ręką ludzką stworzonej ikony, czyli ikony, która powstała cudownie i bezpośrednio z podobizny Chrystusa. Po grecku takie obrazy były nazywane acheiropoietoi. Najbardziej znanym z nich był Mandylion chusta z portretem Chrystusa, który jakoby uratował od najazdu Persów miasto Edessę na północy Syrii. Przechowywano go w Konstantynopolu. Weronika w rzymskiej katedrze św. Piotra miała zaćmić Mandylion z Konstantynopola. Obrazy te miały ogromne znaczenie. Po pierwsze, świadczyły one o akceptacji kultu ikon przez Chrystusa. Po wtóre, były one niemal fizycznymi wyrazami inkarnacji. „Wcielenie w istotę ludzką bez zapładniającego udziału człowieka i obraz stworzony bez udziału malarza zostają potraktowane jako zjawiska paralelne. Obraz jest niejako widzialnym dowodem na podstawowy dogmat wcielenia się Boga w człowieka, które powtórzyło się w jego upostaciowieniu się w ziemskiej materii płótna" ${ }^{36}$. W tym kontekście nieprzypadkowy jest trwały związek Mandylionu z sakramentem Eucharystii. W rytach liturgicznych szczegółowo reglamentowano wykorzystanie przykryć dla Świętych Darów. Za jedno z najbardziej ważnych przykryć liturgicznych uważano „epitalion”. Miał on swoje ważne miejsce w liturgii Wielkiej Soboty. Różnica między nim a Mandylionem zawierała się w tym, że na pierwszym widniał obraz martwego Chrystusa, a na drugim - żywego. Ale związek eucharystycznego epitalionu i Mandylionu nie budzi wątpliwości ${ }^{37}$. Jeffrey

35 Obraz ten zyskał nazwę „prawdziwego obrazu” - vera icona. Grecka etymologia imienia Weroniki - „niosąca zwycięstwo”.

36 H. Belting, Obraz i kult. Historia obrazu przed epoką sztuki. Przeł. T. Zatorski, Gdańsk 2010, s. 67.

37 Gogol opisuje eucharystyczną funkcję epitalionu w Rozważaniach o Boskiej liturgii: „I stawia Święty Kielich i Chleb, przedstawiający Ciało Chrystusa, na ołtarzu jakby na grobie. Wrota Carskie zamykają się jakby drzwi Grobu Pańskiego; zasłona nad nimi jest zasnuwana jak straż postawiona na 
Hamburger przytacza mnóstwo faktów o związku Weroniki z Eucharystią i tematem autentycznej obecności Chrystusa. Weronika w ten sposób była czymś przejściowym pomiędzy obrazem i relikwią i częściowo zastępowała w liturgii ciało zmartwychwstałego Chrystusa ${ }^{38}$.

Ciało Chrystusa upodabnia się do tkaniny, jak na przykład u Jana z Damaszku: „Razem z Królem i Bogiem kłaniam się i purpurze ciała, nie jak odzieniu i nie jak czwartej Osobie - nie! - ale jak przynależnej temu samemu Bóstwu (...)"39. Sens Weroniki był ściśle związany z chrześcijańską mitologią tkactwa, zarysowaną już w Protoewangelii Jakuba w II wieku. Maria jest tu przedstawiona jako twórczyni tkactwa. W tej samej Ewangelii mówi się o czerwonej tkaninie, utkanej przez Marię. Jak wyjaśnia Ewa Kuryluk, „wytworzenie purpurowej tkaniny funkcjonuje nie tylko jako aktywny symbol Chrystusa, wplatający się w ciało Marii. Mówi ona także o królewskiej purpurze przyszłego władcy świata, o purpurowym odzieniu, w które rzymscy żołnierze ubrali Króla Żydowskiego" ${ }^{\text {"40. }}$. Biskup Arculf (pomiędzy rokiem 679 i 688) informował, że widział w Jerozolimie nie tylko chustę z "nie ręką ludzką stworzonym” obrazem Chrystusa, ale i tkaninę, utkaną przez Marię. Do niej były wetkane obrazy dwunastu apostołów i portret Pana; „Część tej tkaniny jest koloru czerwonego, a druga strona - zielona jak trawa" ${ }^{41}$. Tkanina i tkactwo - jako metafory chory - zupełnie słusznie występują tu jako znaki pierwotnej materialności wcielenia. Ale wskazują one także na odrębność dwóch natur w Chrystusie, podobnie jak nie mieszają się nici, składające się na tkaninę.

W interesującym nas kontekście ten motyw materialności zyskuje szczególne znaczenie, kiedy w późnym średniowieczu lub w epoce wczesnego renesansu pojawia się nowy motyw ikonograficzny - twarz Chrystusa, oddzielającego się od chusty i jakby zawisająca przed nią (il. 1). Przy czym chusta, zazwyczaj wykonana w technice trompe-l’oeil, zachowuje zmarszczki, podczas gdy twarz, wyłaniająca się z chusty, absolutnie je ignoruje. $\mathrm{W}$ takim nowym ujęciu oblicze Chrystusa występuje jednocześnie i jako dematerializacja (oddzielenie się od chusty, oderwanie się od jej plecionej osnowy), i jako figuracja. Obraz, wpleciony w osnowę tkaniny, nabiera charakteru wyobrażanej fikcji, różnica wytwarza obraz. Ta fikcja cudownie pozwala nam wejść w kontakt z cielesną całością obrazu. Fantazmat osiąga tutaj stopień halucynacyjności. Obraz, występujący z tkaniny, osiąga ten kres, poza którym można już iść tylko w kierunku jego destrukcji.

warcie. Jerej zdejmuje z głowy diakona święty diskos jakby zdejmował Ciało Zbawiciela z krzyża, stawia go na rozścielony antymins jak na epitalion. Działaniom tym towarzyszą jego słowa: Szlachetny Józefie, z drzewa zdejmij Przeczyste Twoje Ciało, całunem czystym owiń i wonnościami, do grobu nowego złóż" (N. W. Gogol, Duchownaja proza, s. 316-317).

38 J.F. Hamburger, The Visual and the Visionary. Art and Female Spirituality in Late Medieval Germany, New York 1998, s. 333-345.

39 Св. Иоанн Дамаскин, Три слова в защиту иконопочитания, Санкт-Петербург 2001, s. 32.

40 E. Kuryluk, Veronica and her cloth: history, symbolism, and structure of a "true" image, Cambridge - Oxford 1991, p. 97.

41 R. Cornack, Painting the Soul. Icons, Death Masks and Shrouds (Essays in Art and Culture), London 1997, p. 96. 
U Gogola złudzenie Czartkowa, że „straszne oczy zaczęły przeświecać nawet przez płótno", jest jakby parodystycznym występowaniem obrazu z Weroniki. W pierwszej wersji opowieści to występowanie zostało ukazane w sposób jeszcze bardziej dramatyczny: „Widział, jak powierzchowność starca oddzielała się i zstępowała z obrazu, tak jak z gotującego się płynu zdejmuje się wierzchnią pianę, wznosiła się w powietrze i płynęła ku niemu coraz bliżej, aż zbliżyła się do samego jego łóżka"ł2.

Gogol dosłownie zarysowuje powstanie portretu jako niestworzonej ręką ludzką Weroniki. Wszystko dzieje się tak, jakby twarz modelu miała jakąś nadnaturalną energię, pozwalającą mu oddzielać się od siebie samego w postaci obrazu i przenosić się na płótno; co prawda, ważną rolę w procesie tego przenoszenia odgrywa portrecista, nieobecny w Weronice:

«- Tam do licha, jak teraz dobrze oświetlona jest jego twarz! - pomyślał i zaczął pośpiesznie malować, jakby w obawie, że zniknie korzystne oświetlenie. - Cóż za siła! - powtarzał w myśli. - Jeżeli chociaż w połowie przedstawię go takim, jakim teraz wygląda, to przyćmi wszystkich moich świętych i aniołów; zbledną wobec niego. Cóż za diabelska moc! Po prostu wyskoczy mi z płótna, jeśli choć trochę uchwycę podobieństwo. Cóż za niezwykłe rysy!» - wciąż powtarzał malując z coraz większą pasją i sam już widział, jak niektóre rysy zaczęły się przenosić na płótno ${ }^{43}$.

Twórca portretu, mimo że jego pośrednictwo wydaje się prawie mechaniczne, w rzeczywistości aktywnie uczestniczy w przenoszeniu rysów twarzy z oryginału na płótno:

Jednakże mimo wszystko postanowił ze ścisłą dokładnością oddawać każdy nieuchwytny rys i wyraz. Przede wszystkim skupił uwagę na oczach. Promieniowały z taką siłą, że zdawało się niepodobieństwem wyrazić je na płótnie. Mimo to za wszelką cenę postanowił doszukać się w nich najdrobniejszej kreseczki i odcienia, zbadać ich tajemnicę... Lecz skoro tylko zaczął wnikać i zagłębiać się w nie pędzlem, w duszy jego znów odrodziła się dziwna niechęć, taki niezrozumiały ucisk, że musiał na jakiś czas poniechać pracy, by potem znowu do niej wrócićc ${ }^{44}$.

Im bardziej mechanicznie dokładny stara się być malarz, tym bardziej wewnętrznie wciągany jest $\mathrm{w}$ tworzenie portretu. Tymczasem brak wszelkiego pośrednika ma ogromne znaczenie dla rozumienia sensu Mandylionu. Nadnaturalność ikony jest zasadnicza dla jej teologii. Teologia ta powstała $\mathrm{w}$ walce $\mathrm{z}$ bizantyjskim ikonoklazmem. Ikonoklaści, uzasadniający swoje stanowisko decyzjami ikonoklastycznego Soboru 754 roku, odrzucali świętość ikon, twierdząc, że jeśli na ikonie zostaje przedstawiona jedynie ludzka natura Chrystusa, to ikony wpadają w herezję nestorianizmu. Jeśli zaś, zdaniem Soboru, ikony przedstawiają boską stronę Chrystusa, to jest to niemożliwe z powodu niemożności przedstawienia boskości. Jeśli zaś ikony przedstawiają zespolenie boskiej i ludzkiej natury, to wpadają one w monofizytyzm.

Ikonoklastyczna teologia była wyrazem powierzchownie, platonicznie pojętej dogmatyki wcielonego słowa, utrwalonej w dokumentach Chalcedońskiego Soboru Powszechnego, według którego boska i ludzka natura przebywają w Chrystusie od-

42 Н.В. Гоголь, Собрание сочинений. Т. 3, Москва 1953, s. 249.

43 M. Gogol, Opowieści..., s. 145.

44 Tamże, s. 145. 
dzielnie ${ }^{45}$. Ikonoklaści oskarżali czcicieli ikon o wielbienie „substancji” i nie byli w stanie pojąć twierdzenia o przebóstwieniu substancji ${ }^{46}$. W takiej perspektywie jedynym prawdziwym obrazem wcielonego Słowa jest eucharystia. Tylko w sakramencie eucharystii obraz (prosfora, wino) jest tożsamy z boskim praobrazem. Ponieważ wszelkie przedstawienie ze swój natury odróżnia się od praobrazu, to jest ono fałszywe.

Jeszcze przed ikonoklastycznym Soborem Jan z Damaszku upodobnił ikonę do prosfory. Oczywiście, ikona nie jest ciałem Chrystusa, ale podobnie jak ludzkie ciało Chrystusa jest święte i przepełnione łaską, tak samo obraz Chrystusa staje się po komunii nosicielem łaski: „Zatem wielbię substancję, poprzez którą uczyniło się moje zbawienie, oddaję jej cześć i składam hołd. Ale wielbię nie jak Boga, lecz jako przepełnione boskim działaniem i łaską. Czyż nie materią jest drzewo krzyża, trzykroć szczęśliwe i błogosławione?" " samo ciało Chrystusa może uświęcić stworzoną materię. Ikona w takiej perspektywie staje się ontologicznie tożsama z Chrystusem, ale tożsamość ta dotyczy energii i łaski, ale nie samej zniszczalnej materii drzewa.

Bardziej wyrafinowaną wersję teologii ikony, która stała się późnej kanoniczną, przedłożył Teodor Studyta. Jego zdaniem praobraz znajduje się w ikonie nie pod względem istoty, lecz „pod względem podobieństwa swojego bytu”. W ikonie przebywa nie energia i łaska, lecz Hipostaza Boga. Hipostaza zaś (persona) cechuje się swoim zindywidualizowaniem, w którym wyraża się samoograniczenie Boga w tej hiposta$\mathrm{zie}^{48}$. Oto wywód Studyty:

Człowiek w ogóle jest imieniem pospolitym, jeśli zaś ktoś nazywa się na przykład Piotr lub Paweł, to jest to imię własne. Razem z imieniem własnym może się on także nazywać i ogólnym lub pospolitym imieniem. Przecież Paweł nazywa się też człowiekiem, gdyż posiada on właściwości, wspólne z oddzielnymi przedmiotami i indywiduami tego samego rodzaju; ponieważ zaś wyróżnia się osobistymi przymiotami, nazywa się Pawłem. Dlatego jeśliby Chrystus, wcielając się w człowieka, nazywał się w Piśmie tylko Bogiem i człowiekiem, to oznaczałoby, że przyjął tylko wspólną naszą naturę, względem której już wcześniej udowodniono, że jeśli ją kontempluje

45 Э. Зендлер, Генезис и богословие иконы, „Символ” 1987, nr 18, s. 45.

46 Wiktor Żywow pisze: „(...) u podstaw protestu ikonoklastów tkwi wyobrażenie o niemożliwości przebóstwienia materii. Wyobrażenie to wskazuje na ikonoklastów jako na spadkobierców hellenistycznego dziedzictwa światopoglądowego: podstawowa dla myśli antycznej opozycja materialnego i noetycznego odsuwa na dalszy plan podstawową dla myśli biblijnej opozycję Boga i stworzenia. Duchowe (noetyczne) jest dostępne przebóstwieniu (choć i ono jest stworzone), materialne zaś przebóstwionym stać się nie może. W swoim czasie G. Fłorowski pisał, że «ikonoklaści (...) demonstrują nieprzetworzoną i nieidącą na kompromisy hellenistyczną pozycję spod znaku Orygenesa lub Platoпа»" (В.М. Живов, Богословие иконы в первый период иконоборческих споров. W: В.М. Живов, Разыскания в области истории и предыстории русской культуры, Москва 2002, s. 52).

47 Св. Иоанн Дамаскин, Три слова в защиту иконопочитания..., s. 65.

48 Rozdzielenie natury i osoby przeprowadził Grzegorz z Nyssy w „trzydziestym ósmym liście św. Bazylego do swego bata Grzegorza”. „Natura (ousia) to jest to, co jest wspólne. Osoba znajduje się niżej i wskazuje na osobność, istniejącą pomimo tego, co jest wspólne. 'Człowiek' oznacza ousia, zaś konkretny człowiek ze swoim imieniem, oddzielony od tej wspólności jest osobą” (А. Безансон, 3aпретный образ: Интеллектуальная история иконоборчества. Пер. с фр. М. Розанова, Москва 1999, s. 130). 
się w oddzielnej osobie, to ona wcale nie istnieje. Ale Gabriel mówi Dziewicy: „Oto poczniesz i porodzisz Syna, któremu nadasz imię Jezus” (Łk 1:31). Zatem Chrystus został nazwany nie tylko pospolitym, ale i własnym imieniem, który wyróżnia go hipostazowym lub osobowymi właściwościami spośród innych ludzi; wskutek tego jest on i opisywany ${ }^{49}$.

Gdyby zrekapitulować tę myśl Studyty o hipostazowości, to całkowicie mieści się ona w sferze rozróżnienia, w sferze ekstremalnej indywiduacji, choć dzisiejszy czytelnik oczywiście nie odbierze ikony w perspektywie indywidualizacji.

Właśnie absolutna wyjątkowość oblicza Chrystusa, wypływająca z ograniczoności jego hipostazowości, czyni ikonę w ogóle możliwą. Studyta swoiście rozwija twierdzenia innego teoretyka ikony, patriarchy konstantynopolskiego Nikifora, który odróżniał opisanie lub zarys (perigrafe) od obrazu. Zgodnie z myślą Nikifora zarysu lub opisania nie można zastosować do praobrazu właśnie dlatego, że go indywidualizują, a zatem, przywiązują do określonego miejsca i czasu. Opisywalność jest jedną z istotnych cech stworzonego świata. Hipostaza jest wprost związana z zarysem, czyli z rozróżnieniem i syngularnością, podczas gdy praobraz zakorzeniony jest jedynie w ogólnym pojęciu substancji lub natury, które indywidualność pozostawia nieokreśloną (aperigraphon). Hipostaza jest powiązana $\mathrm{z}$ naturą, gdyż zawsze jest skorelowana $\mathrm{z}$ całością innych hipostaz, w których ousia (natura) znajduje wyraz. Tak oto piękno Chrystusa jest również pięknem Ojca, tylko pierwsze jest stworzone, a druga - niestworzone.

Hipostazowość ikony, czysto zindywidualizowane podobieństwo - zdaniem Studyty - nie należy do „substancji”, lecz pozostaje poza „substancją”. I właśnie w tym kontekście zaczyna odgrywać zasadniczą rolę nadnaturalność Mandyliona. W Liście do Platona o czczeniu ikon Teodor zwraca się w celu zilustrowania swojej myśli ku metaforze pieczęci:

Niech będzie pierścień, na którym wyrysowano obraz króla i niech będzie on odciśnięty na wosku, na smole, na glinie. Pieczęć oczywiście będzie ta sama i niezmienna na wszystkich substancjach; substancje zaś będą się od siebie różnić; [pieczęć] nie mogła nie pozostać niezmienną na rozmaitych [substancjach], jako niemająca nic wspólnego z materiałami; ale, oddzielona od nich myślą, pozostaje na pierścieniu. W ten sposób również podobizna Chrystusa, niezależnie od substancji, na której byłaby narysowana, nie ma [nic] wspólnego z substancją, na której jest przedstawiana, pozostając w osobie Chrystusa, do którego ona należy ${ }^{50}$.

$\mathrm{W}$ ideale ikona ma sens jedynie w tej mierze, w jakiej ona jest bezpośrednim hipostazowym odbiciem, dlatego iż żadne mimetyczne kopiowanie nie może dokładnie odtworzyć rysów twarzy Chrystusa. Mimetyczne kopiowanie natychmiast wstępuje $z$ oryginałem w platoniczne relacje kopii, która nigdy nie może być w pełni adekwatna. $\mathrm{W}$ dodatku mimetyczne, reprezentatywne odtworzenie, przechodząc przez podmiot (artystę), zawsze traci absolutność swojej syngularności (jak znika w reprezentacji miejsce i czas przedstawionego zdarzenia, indywidualizujący go kontekst). Reprezentacja nieodwracalnie, choćby częściowo, przemienia Piotra i Pawła w „człowieka w ogóle".

49 Феодор Студит, Третье опровержение иконобориев, „Символ” 1987, nr 18, s. 302.

50 Феодор Студит, Послание Платону о почитании икон. Первое опровержение иконобориев. Второе опровержение иконобориев. Третье опровержение иконобориев, „Символ” 1987, $\mathrm{nr} 18$, s. 252. 
Odbicie jest najlepszym sposobem na dotarcie do prototypu ${ }^{51}$. Samo słowo typos, odgrywające ważną rolę w teologii ikony, etymologiczne wywodzi się z czasownika typtô - 'bić, wybijać, uderzać - w tym samym znaczeniu, w jakim mówi się o wybijaniu medali lub biciu monet. Młotek po grecku jest he typas, he typis. Ho typos odpowiednio oznacza odcisk, zrobiony pieczęcią, monetą lub sygnetem-pieczęcią ${ }^{52}$. Typos jako typ, prototyp osiąga się nie poprzez reprezentację, ale właśnie poprzez odbicie.

Nie ręką ludzką stworzony obraz powstał według modelu pieczęci. Ale pieczęć ciekawa jest przez to, że odcisk zawsze pozwala dotrzeć do oryginału, samej pieczę$\mathrm{ci}^{53}$. W końcu nadnaturalny obraz, Weronika okazuje się cudownym środkiem dotarcia do samej pieczęci. Rumuński historyk Daniel Barbu w ten sposób podsumowuje możliwości, ujawnione przez teologię ikony patriarchy Nikifora, a zwłaszcza Teodora Studyty:

Jeśli można reprezentować tylko to, co w rzeczywistości istnieje lub miało pozorne istnienie i jeśli ta rzecz zawiera w sobie swoją własną reprezentację, wówczas w instancji, wytwarzającej wypowiedź (dans l'instance énonciatrice), jaką jest spojrzenie, można odwrócić porządek prawdziwości, lub - innymi słowy - logiczną zasadę podobieństwa. I rzeczywiście, w bizantyjskim obrazie, w ikonach, czasami zdarza się tak, że sam obraz powołany jest do tego, by odtwarzać własny praobraz zgodnie z regułą podobieństwa ${ }^{54}$.

Właśnie powstanie oryginału z kopii jest fabułą licznych malarskich Weronik. Prawdopodobnie jest to ten efekt, który chce osiągnąć złowrogi lichwiarz, uciekający się do portretu jako do ostatniej możliwości przeżycia ${ }^{55}$.

Padł mu do nóg i błagał, aby dokończył portretu, mówiąc, że od tego zależy jego los i pozostawanie na świecie, że malarz już dotknął swym pędzlem jego żywych rysów i jeśli odda je wiernie, to życie nadprzyrodzoną mocą utrwali się w portrecie, że wtedy nie umrze zupełnie, lecz będzie istniećs ${ }^{56}$.

51 U Gogola fiksacja ściśle indywidualnych póz postaci w finałowej scenie Rewizora jest podobna do tego rodzaju odbić.

52 D.F. Krell, Of Memory, Reminiscence, and Writing on the Verge, Bloomington 1990, s. 23.

53 Pieczęć, tworząc odciski w różnych materiałach, zachowuje w nich identyczność niematerialnej formy (hipostazy). Nim model ten zastosowano do ikon, używano już jej w stosunku do obrazu imperatora, zachowującego swoją identyczność w materiałach różnych obrazów. Przeniesienia imperatorskiego modelu na Chrystusa dokonał św. Bazyli, utrzymujący, że „posąg cesarza, nazywany «imperatorem», zachowuje identyczność w rozmaitych odlewach. Właśnie ta identyczność, nazywana «imperatorem», jest identycznością jednej i tej samej formy” (M. Barash, Icon. Studies in the History of an Idea, New York 1995, s. 276). To twierdzenie św. Bazylego stale było cytowane przez teoretyków ikony.

54 D. Barbu, L'image byzantine: production et usages „Annales HSS” (Janvier-février) 1996, vol. 51, s. 77.

55 Mowa o złowrogo-romantycznym potraktowaniu tematu reprezentacji, o którym pisał już Alberti: „Malarstwo zawiera w sobie boską siłę, która nie tylko czyni nieobecnego człowieka obecnym, podobnie jak - wedle powszechnej opinii - przyjaźń, ale - co więcej - czyni martwego wyglądającym niemal jak żywy (...) Niewątpliwie, twarz zmarłego człowieka dzięki malarstwu żyje długim życiem” (L.B. Alberti, On Painting, New Haven 1966, s. 63).

56 M. Gogol, Opowieści..., s. 120-121. 
Obraz jawi się jako jedyny sposób dla Antychrysta, niemającego boskiej istoty, pozostanie wiecznie żywym. Lichwiarz pragnie przeżyć nie w istocie, lecz w hipostazie, pozbawionej istotowego sensu.

U Gogola dzieje się coś nieprzewidzianego. W relację kopii i oryginału wciągnięty zostaje malarz. W sytuacji pieczęci, którą reprodukuje się w Weronice, twarz Chrystusa bezpośrednio odbija się na nosicielu. Powstający ślad ma indeksalny charakter ${ }^{57}$. Ale zgodnie z logiką, zaznaczoną przez Barbu, za pomocą rewersji „porządku prawdziwości” z indeksów i śladów może powstać praobraz, mający ikoniczny charakter. Dzięki spotkaniu znaku ikonicznego i indeksalnego na miejscu śladu powstaje obraz ${ }^{58}$. Nieforemne plamy, tworzące ślad, w obrazie mimetycznym przemieniają się w formę obraz. Marie-Christine Poirée pisze, że reprezentacja i prezentacja zawsze znajdują się w złożonych relacjach wzajemnych. Przez reprezentację rozumie ona obraz ikoniczny, zaś przez prezentację ten zestaw elementów materialnych, $\mathrm{z}$ których obraz ten powstaje: „Zazwyczaj reprezentacja pociąga za sobą stłumienie pisma, śladu, pracy oznaczania, substancji znaku. Reaktywacja śladu, graficznego popędu i ciała nosiciela unosi się nad systemem reprezentacji jak wewnętrzne zagrożenie" ${ }^{\prime 59}$. Zagrożenie to jest dobrze widoczne w Nieznanym arcydziele, na którym ślady pędzla Frenhofera, wysuwając się na plan pierwszy, ujawniają indeksalną podstawę malarstwa i tym samym podważają jego wymiar reprezentatywny. Obraz kobiety znika z płótna, które staje się diagramem chaotycznych śladów działalności artysty.

Pełna zbieżność śladu i kopii możliwa jest tylko wówczas, kiedy zarówno ślad, jak i kopia należą do tej samej osoby. Tak oto w Weronice obraz Chrystusa powstaje ze śladów, pozostawionych na płótnie przez jego twarz. Taki system pozwala ikonie zachować orientację na ślad, ale wtedy ikona nie powinna być wykonana ręką ludzką. Sytuacja się zmienia, kiedy ślady na płótnie należą do jednego (malarza), zaś reprezentowany jest inny (model). Reprezentacja dąży do maksymalnego stłumienia śladu; co za tym idzie, jest ona zorientowana również na szczególną formę obecności, która przestaje kojarzyć się z obecnością odcisku, nadającego reprezentacji charakter prawdziwości. Reprezentacja rzadko pretenduje do gwarantowanej autentyczności i dlatego łatwo przesuwa się w dziedzinę iluzji.

Ale ślad nie może być całkowicie wyparty. Artysta nieodwracalnie jest obecny w tworzonym przez siebie obrazie. Co prawda, artysta, szczególnie w portrecie, staje się ekwiwalentny podmiotowi w szerokim sensie słowa.

Portret (to, że u Gogola mówi się o portrecie, a nie o innym gatunku, jest niezwykle ważne) wyraża paradoksalność relacji czynnika ikonicznego i indeksalnego ze

\footnotetext{
57 Tego, że ślad w praktyce kultu ikon może być ważniejszy od obrazu, dowodzi swego rodzaju rytuał dotykania cudownej ikony kawałkami tkaniny, które następnie rozdawano wiernym na placu w Konstantynopolu. Znaczenie powstających relikwii, imitujących dotykanie chustą twarzy Chrystusa, całkowicie utrwala się w niewidzialnym śladzie (zob. o tym rytuale: R. Cornack, Painting the Soul. Icons..., s. 61).

58 O próbach przemieniania indeksalnych śladów w „obraz”, „przełożenia” plamy na całunie turyńskim w ikonę ukrzyżowania Chrystusa i teoretycznych skutkach tych prób zob. G. Didi-Huberman, The Index fo the Absent Wound (Monograph on a Stain). W: October. The First Decade. Ed. by A. Michelson et al., Cambridge, Mass. 1987, s. 39-57.

59 M.-Ch. Poirée, Lempreinte Au XXe siècle. De la Vèronique au „Verre ironique”, Paris 1997, s. 36.
} 
szczególną siłą. Portret odznacza się kilkoma ważnymi osobliwościami, o których należy wspomnieć. Zwykle reprezentuje on nieruchomą, izolowaną figurę ludzką, której przypisujemy podobieństwo do pewnego prototypu. Paradoksalnie, ale możemy określić portret jako obraz, o prototypie którego nic nie wiemy. W muzeach jest mnóstwo takich portretów nieznanych nam ludzi. W pewnych wypadkach toczą się wieloletnie spory o przynależność niektórych obrazów do gatunku portretu, jak na przykład $Z$ żdowska narzeczona Rembrandta ${ }^{60}$. Sama możliwość takich sporów pokazuje, że dla ustanowienia podobieństwa portretu nie ma potrzeby znajomości oryginału. Inaczej mówiąc, podobieństwo portretowe nie jest referencyjne. Nie odsyła ono do modelu, będąc - by tak rzec - samowystarczalnym podobieństwem. Portret jest nosicielem podobieństwa jako takiego, nieodsyłającego do realnego człowieka poza sobą. W tym tkwi jego fundamentalna odmienność od Weroniki, której ślady są indeksalne, czyli mają bezpośrednią funkcję referencyjną.

Paul Valery tak pisał o tej dziwnej właściwości portretu:

«Coś mi mówi», że jest to popiersie... Tytusa jest niezwykle podobne.

Bez wątpienia nazwę Prawdą tę zbieżność mojej idei Tytusa i tego marmuru, mnie, który nigdy nie widział Tytusa i tego popiersia, stworzonego w XVI wieku.

Dawny wielki spór z Marcelem Schwobem przed Kartezjuszem Halsa: znajdował go niepodobnym.

- Do kogo? - zapytywałem go ${ }^{61}$.

Do kogo podobny jest Tytus lub Kartezjusz Halsa? Do idei podobieństwa i w ostatecznym rachunku do samego siebie. Głębokie rozmyślania o tego rodzaju niereferencyjnym podobieństwie należą do Mourice Blanchot. Blanchot twierdził, że podobieństwo nie odnosi się do dziedziny imitacji życia, lecz odwrotnie - czyni ono życie nieosiągalnym, „przemieniając je w stałego sobowtóra, uciekającego przed życiem. Żywe figury, ludzie, nie mają podobieństwa" ${ }^{62}$. Pisał on, że podobieństwo staje się udziałem ludzi o martwym wyglądzie zewnętrznym, jest ono skutkiem tej idealizacji, którą może rzucić na oblicze człowieka śmierć. Piękno w takim kontekście okazuje się samoodbiciem, trafiającym do rubryki podobieństwa.

Portret - staje się to powoli oczywiste - nie jest podobny, ponieważ zyskuje on podobieństwo do twarzy, a raczej podobieństwo dopiero zaczyna się i istnieje razem z portretem i tylko z nim! Podobieństwo jest pochodne od portretu; jego wielkością i hańbą; wiąże się z pracą, wyraża fakt, że twarzy tutaj więcej nie ma, że jest ona nieobecna, że prezentuje siebie tylko z powodu nieobecności, która jest właśnie podobieństwem i ta nieobecność jest również formą, którą przyjmuje czas, kiedy świat się oddala i kiedy z niego pozostaje tylko ta przepaść i ta odległośćc ${ }^{63}$.

Zgodnie z Blanchot podobieństwo przejawia się dwojako: z jednej strony poprzez nieobecność osoby, zniknięcie modelu. Podobieństwo jest to przypominanie o nieobecności. Z drugiej strony podobieństwo zaznacza się w formach podwojenia, sobowtórstwa, które utrwala tę nieobecność w hermetycznej strukturze, do wewnątrz której

60 Zob. S. Alpers, Rembrandt's Enterprise, Chicago 1988, s. 89.

61 P. Valery, Tel Quel. W: P. Valery, Oeuvres. T. 2, Paris 1960, s. 622.

62 M. Blanchot, Friendship. Transl. by E. Rottenberg, Stanford 1997, s. 32.

63 Tamże. 
przeniknąć nie sposób. Innymi słowy, podobieństwo zastępuje referencję w stosunku do modelu skoncentrowanego na sobie narcystycznym podwojeniem. Transformacja ta wyraża ogólną metamorfozę, której podlega dyskurs (czyli zdarzenie wypowiedzi), kiedy przemienia się w tekst (czyli piśmienny dokument, tracący właściwości referencyjności). Referencja (wskazanie na model) jest wymieniana na autoreferencję, czyli właśnie na dziwny efekt identyczności, podobieństwa do samego siebie. Stąd się bierze typowe odizolowanie portretowanych osób, ich bezczynne nieuczestniczenie w otaczającym ich świecie. Izolacja portretowanej osoby to forma realizacji podobieństwa.

Georg Simmel na początku XX wieku utrzymywał, że w portretach psychologicznych, na przykład u Rembrandta, podmiot malarstwa, artysta przedstawia swoje "Ja" w formie "Wy”, czyli w postaci cudzego ciała portretowanego. Stąd też wrażenie życia portretu, które jest odbiciem subiektywnej energii jego twórcy w cudzym ciele ${ }^{64}$. Jean-Luc Nancy wyraził przekonywające przypuszczenie, że w portrecie realizuje się podobieństwo z podmiotem malarstwa. Takim podmiotem może być i malarz, i widz: „Podmiot portretu to podmiot $\mathrm{w}$ tej mierze, w jakiej należy do samego siebie (en tant qu'il est à soi)..." ${ }^{65}$. Podmiot rozpoznaje siebie w odizolowaniu portretu. W samej strukturze portretu „ślad”, „odcisk” malarza zyskuje obraz. Właśnie tutaj następuje przejście od chaosu niemających formy śladów do całościowości iluzorycznej formy jako reprezentacji. Ale reprezentacja w portrecie okazuje się dziwna. Reprezentując model, w rzeczywistości narcystycznie odtwarza w sobie podmiotową strukturę relacji artysty do swojego dzieła. Odtwarza ona również strukturę samego świata iluzji w jego odizolowaniu od życia, w jego geometrycznej samowystarczalności. Nancy pisze o tym, że portret nawet nie tyle jest reprezentacją podmiotu, co subiektywności, czyli „bycia-samym-sobą” (être-soi) jako takiego. Aleksandr Gabriczewski, który zajmował podobne stanowisko, w ogóle twierdził, że portret pojawia się w malarstwie dopiero wówczas, kiedy może rozwinąć się system tak zwanych „form ekspresywnych”, czyli kiedy malarstwo opanowuje instrumentarium dla przekazu subiektywności ${ }^{66}$. W portrecie - zdaniem Nancy - „podmiot wchodzi w relację z samym sobą i w ten sposób okazuje się zbieżny z samym sobą". „Być podobnym do siebie - to nic innego, jak być sobą i tym samym, co ja" ${ }^{\prime \prime}$.

Ta sytuacja reprezentowanej subiektywności jest niezwykle złożona. Przecież podmiot ostatecznie jest tym, kogo nie ma na płótnie, w obrazie. Pod tym względem por-

64 G. Simmel, Rembrandt: An Essay in the Philosophy of Art. Transl and ed. by A. Scott, H. Staubmann, New York-London 2005, s. 20-27.

65 J.-L. Nancy, Le Regard du portrait, Paris 2000, s. 28.

66 „Malarstwo europejskie od czasów Odrodzenia, a przede wszystkim od Baroku do naszych czasów, staje się w miarę przeważania momentów ekspresywnych coraz bardziej portretowe. W tym też sensie należy rozumieć tak ulubione powiedzenie, że każdy portret jest autoportretem. Można byłoby iść dalej i twierdzić, że malarstwo sztalugowe tej epoki zawsze ma odcień i portretu i autoportretu. Narzuca się myśl, że osoba ludzka w całej swojej pełni może być utrwalona w malarstwie tylko dzięki obecności i rozwoju właśnie form ekspresywnych, czyli tylko dzięki temu, że obraz, przedstawiający osobę, nie tylko w swojej budowie operuje swoistymi «osobowościowymi» formami, ale też jest wyrazem i odbiciem osoby, która go stworzyła" (А.Г. Габричевский, Морфология искусства, Москва 2002, s. 296).

67 J.-L. Nancy, Le Regard du portrait..., s. 47. 
tret, jak zauważa ten sam Nancy, wpisuje w siebie śmierć i Boga - te elementy transcendentalne, które są obecne w charakterze nieobecności.

Paradoksalność struktury portretu zawiera się w tym, że oferuje on nam obraz podobieństwa, izolacji i samowystarczalności tego, co jest nieobecne. W charakterze autonomicznego, hermetycznego, izolowanego tworu portret nigdy w pełni nie należy do swojej przestrzeni, postać na nim jest jakby wyrzucana lub wypychana na zewnątrz. Pod tym względem oddziałuje on podobnie jak klasyczne Weroniki, które jakby rzutują unoszącą się głowę Chrystusa przed tkaninę, na której odcisnęly się jej ślady. Głowa Chrystusa, podobnie jak twarze licznych portretów, choć oczywiście znacznie bardziej radykalnie, jest wyrzucana $\mathrm{z}$ płótna $\mathrm{w}$ przestrzeń konstruowania reprezentacji, w tę przestrzeń przed płótnem, w którym znajduje się podmiot. Mowa tu o braku, śmierci, które - jako obraz - występują z przestrzeni reprezentowanej i wchodzą w przestrzeń reprezentowania. Właśnie tutaj podmiot spotyka swoje narcystyczne odbicie jako podobieństwo.

Louis Marin zestawił Weronikę $e^{68} \mathrm{z}$ motywem, zdawałoby się, przeciwstawnym pod względem treści - Meduzą Gorgoną. Marin porównał portretowanie z odrąbywaniem głowy modelowi. Motyw ten często spotyka się u Caravaggia (il. 2), który stworzył jeden z najbardziej znanych obrazów odciętej głowy Meduzy. W obrazie dekapitacji Holofernesa przez Judytę Caravaggio próbował utrwalić niereprezentowany moment, kiedy miecz oddziela głowę od ciała i wytycza granicę pomiędzy życiem i śmiercią. Marin pisał: „(...) moment działania unieruchamia się samą reprezentacją jego momentalności. Cios jest zablokowany w środku swojego wykonania. Judyta nigdy nie kończy odcinania głowy Holofernesa swoim zatrzymanym mieczem (...)"69. Ale to unieruchamianie działania poprzez akt malarskiej reprezentacji zbliża ostatnią do działania spojrzenia Meduzy, przemieniającej swoim spojrzeniem ludzi w kamień.

W takim kontekście głowa Meduzy, przymocowana do tarczy Perseusza, staje się swego rodzaju alegorią malarskiej reprezentacji. W „portrecie” Meduzy podmiot malarstwa rzeczywiście spotyka samego siebie, swoją własną subiektywność. Oczywiście, znamienne jest też to, że występowanie Meduzy z tarczy strukturalnie jest zbieżne $\mathrm{z}$ występowaniem głowy Chrystusa $\mathrm{z}$ chusty Weroniki. W obydwu wypadkach podmiot ujawnia się w narcystycznym podwojeniu, przyjmującym formę wysunięcia figury (głowy) z reprezentacyjnej przestrzeni i włączenie jej w przestrzeń reprezentowania, w którą wpisany jest podmiot.

Słowa Marina w pełni odnoszą się do tradycji zachodnioeuropejskiego iluzjonistycznego malarstwa, ale, ma się rozumieć, nie odnosi się do malarstwa ikonowego, które upatruje $\mathrm{w}$ sobie prawie mechaniczne odtworzenie nadnaturalnego obrazu. Ponieważ w tradycji Mandylionu artysta (podmiot) jakby nie uczestniczy i mówi się o magicznym śladzie samej twarzy Chrystusa, obraz nie może stać się narcystycznym zwierciadłem samego podmiotu, malarza przede wszystkim. Hipostazowa jednostkowość twarzy również wyklucza Mandylion z sytuacji portretowania, w której zawsze przebija się coś wspólnego.

68 O Weronice zob. L. Marin, Philippe de Champaigne ou la présence cachée, Paris 1977.

69 L. Marin, Détruire la peinture, Paris 1977, s. 167. 
W tym kontekście szczególne zainteresowanie wzbudza autoportret, w którym jakby nie ma pośrednika, gdyż sam malarz odciska się na płótnie (i to zbliża go do Weroniki). Zresztą wszelki portret częściowo okazuje się autoportretem. W autoportrecie połączenie czynnika indeksalnego z ikonicznym jest przepuszczone przez mechanizm reprezentacji - samoodtworzenia jako innego, jako nieobecnego. Stąd się bierze pośrednicząca i zasadnicza rola zwierciadła w autoportrecie. Bez lustra, jak wiadomo, nie ma autoportretów ${ }^{70}$.

U Gogola portret lichwiarza nieodwracalnie okazuje się autoportretem swego twórcy, który stopniowo odkrywa w sobie przemiany i przejawy takich uczuć, których wcześniej nie doświadczał i które przekazuje mu model. W przyjętej przez Gogola strategii odwracania relacji między oryginałem i kopią twórca staje się kopią stworzonego przezeń dzieła.

Czartkowowi w opowieści Gogola udaje się stworzyć tylko jedno dzieło, w którym przybliża się on do ideału twórczości. Jest to portret anemicznej arystokratycznej panny Lizy. Znamienne, że Czartkow całkowicie ignoruje ludzką istotę swojego modelu, której po prostu nie był w stanie pojąć $c^{71}$. Jego spojrzenie jest czysto zewnętrzne. Model dla niego jest zwykłą kombinacją tonów, odcieni i faktur, jest to czyste pole różnic. Natomiast Czartkow posiadał zdolność do utrwalania najdrobniejszych i prawie niewidzialnych dla oka drobiazgów: „Wyławiał każdy odcień, delikatną żółtość, ledwie dostrzegalne niebieskie cienie poboczami i już gotów był nawet schwycić niewielki pryszczyk na czole"72. Mowa o niemal mechanicznym przenoszeniu cech różnicy, które zajmują Czartkowa znacznie bardziej niż ogólne oblicze modelu, jego całościowy obraz. Czartkow stara się pracować właśnie jak pieczęć, przenosząc cechy z modelu na odcisk. Taka praca nie podoba się matce Lizy, która nalega na idealizację obrazu córki.

\footnotetext{
70 W.S. Turczin, odnotowując szczególne znaczenie autoportretów w rosyjskim malarstwie romantycznym, uważa, iż podstawowa masa autoportretów była tworzona bez pomocy lustra. „Romantyczny autoportret nigdy nie był dokładnym utrwaleniem powierzchowności malarza, jego zadania były inne - pokazanie nastroju człowieka, jego duchowego samopoczucia. W praktyce artystycznej tego rodzaju nastawienia twórcze prowadziły do tego, że wszystkie autoportrety romantyków rosyjskich z pierwszej tercji XIX wieku były malowane bez pomocy lustra, co łatwo można określić na podstawie położenia ręki, w której znajduje się pędzel i ołówek. Tylko o dwóch autoportretach można powiedzieć, że są one wykonane z wykorzystaniem lustra, czyli stawiały sobie za cel dokładne odtworzenie zewnętrznego wyglądu artysty. Tymi dziełami były autorskie obrazy A. G. Wieniecjanowa i W. A. Tropinina (...)" (В.С. Турчин, Эпоха романтизма в России, Москва 1981, s. 194). To twierdzenie Turczina wydaje się mało przekonywające. Namalowanie autoportretu bez lustra jest niemal niemożliwe, jeśli, oczywiście, nie liczyć schematycznej karykatury, w której oblicze sprowadzone jest do kilku charakterystycznych szczegółów. Autoportret bez lustra jest bardziej złożonym zadaniem niż portret bez modelu, gdyż malarz - jak każdy inny człowiek - siebie w zasadzie nie widzi i jest powiązany z obrazem własnej powierzchowności w sposób znacznie bardziej złożony niż z obrazem innego. Wątpliwe, czy ułożenie rąk z ołówkiem i pędzlem może być dowodem, gdyż ujrzana w lustrze głowa $\mathrm{z}$ łatwością przystaje do ciała, którego schemat nie zależy od lustrzanego odbicia.

71 „Gdyby był znawcą ludzkiej natury, w ciągu jednej chwili odczytałby w niej początek dziecinnej namiętności do balów, początek nudów i skarg na to, że czas tak się wlecze przed obiadem..." i tak dalej (M. Gogol, Opowieści..., s. 111-112). Niczego takiego Czartkow nie zauważa.

72 M. Gogol, Opowieści..., s. 114.
} 
W rezultacie Czartkow, ustępując jej naleganiom, eliminuje niektóre ledwo zauważalne ślady różnicy:

Ze smutkiem zaczął zacierać to, co wydobył jego pędzel. Znikło sporo ledwo dostrzegalnych rysów, a wraz z nimi częściowo i podobieństwo. Obojętnie jął nadawać portretowi szablonowy koloryt, który można dawać na pamięć i który przekształca nawet twarze wzięte z natury w jakieś chłodno-idealne twarzyczki widywane zazwyczaj w uczniowskich szkicach ${ }^{73}$.

Moment ten jest niezwykle ważny dla całej estetyki Gogola. Gdy tylko indywidualizujące poruszenie czystej różnicy ustępuje miejsca ogólnemu obrazowi, gdy tylko całościowa totalność wysuwa się na plan pierwszy kosztem cech syngularności, do tekstu wnika trywialność pospolitego i skliszowanego. Nadzieja na stworzenie arcydzieła znika.

Ale na tym historia z portretem Lizy się nie kończy. Po wyjściu modela Czartkow odszukuje zarzuconą główkę Psyche, „którą kiedyś dawno naszkicował” i zaczął rzutować na niego dopiero co utrwalony w jego świadomości oblicze Lizy. W danym wypadku praca idzie w kierunku wprost przeciwnym w stosunku do tego, w którym ona podążała wcześniej. Teraz nie totalność powstaje z syngularności, lecz syngularność projektuje się na totalność. Oto jak Gogol opisuje wyjściowy stan szkicu Psyche i późniejszą pracę nad nim:

Była to twarzyczka ładnie namalowana, ale zupełnie idealna, chłodna, składająca się z samych tylko rysów ogólnych, nie przepojona życiem ciała. Nie mając nic do roboty zaczął dalej szkicować, przypominając sobie podczas pracy wszystko, co udało mu się dostrzec w twarzy arystokratycznego gościa. Uchwycone rysy, odcienie i tony układały się w czyste formy, w jakich stają przed oczami malarza, gdy ten napatrzywszy się na naturę już się od niej oddala i tworzy równie wielkie dzieło. Psyche zaczęła ożywać i to, co było przed chwilą niejasną myślą, zaczęło przybierać widzialne kształty. Typ twarzy młodej, światowej dziewczyny został mimo woli nadany Psyche, a przez to nabrała ona swoistego wyrazu dającego jej prawo do nazwy rzeczywiście oryginalnego dzieła ${ }^{74}$.

Ciekawe, że Czartkow jawi się tutaj dosłownie jako pewna matryca czystych różnic. Jego świadomość zawiera w sobie jedynie „odcienie i tony”, ale w pewnej „oczyszczonej postaci", świadomość artysty staje się podobieństwem pieczęci, na które wygrawerowano zarysy oblicza. Te „odcienie” jakby oddzieliły się od twarzy Lizy i teraz istnieją w stanie czystej różnicy, niezwiązanej z materią. Świadomość Czartkowa okazuje się całkowicie pustą świadomością, nieznającą żadnego całościowego obrazu; jawi się ona nie jako myśląca świadomość, lecz jako czysta mapa linii, odcieni, tonów, oddzielonych od nosiciela. Świadomość Czartkowa jest bardzo podobna do tej samej dziwnej „hipostazowości”, o jakiej mówił Studyta. Bo czymże jest ta hipostazowość, jak nie utrwaloną z maksymalną dokładnością syngularnością różnicy rysów Jezusa, w żaden sposób niezwiązaną z żadnym nosicielem. Przypomnę to ważne stwierdzenie Studyty:

Pieczęć oczywiście będzie ta sama i niezmienna na wszystkich substancjach; substancje zaś będą się od siebie różnić; [pieczęć] nie mogła nie pozostać niezmienną na rozmaitych [substancjach],

73 Tamże, s. 115.

74 Tamże, s. 116. 
jako niemająca nic wspólnego z materiałami; ale, oddzielona od nich myślą, pozostaje na pierścieniu.

Czartkow pracuje nad portretem Lizy jak Weronika. Jego osobista artystyczna ingerencja jest tutaj minimalna. Powodzenie portretu, który tworzy, wiąże się z tym, że idealizowany obraz Psyche jakby nie należy do niego. Jest to martwa uczniowska kopia, którą kiedyś zrobił i o której zapomniał. Czartkowowi udaje się malować obraz bez udziału świadomości i bez żadnego odniesienia do tradycji kulturalnej. Portret ten gatunkowo okazuje się ikoną, napisaną na idealizowanej etiudzie. Ta nieoczekiwana mieszanina prowadzi Czartkowa do sukcesu.

Sukces ten artysta osiąga dlatego, że udało mu się nie włączyć swojego „Ja” do procesu twórczego. Portret Lizy to jedyny jego obraz, który nie jest jednocześnie autoportretem. Ale dzieje się to tak dlatego, że Gogol sztucznie konstruuje sytuację, w której mechanizm imitacji, mimesis został naruszony. To naruszenie relacji mimetycznej następuje dwojako. Z jednej strony świadomość Czartkowa utrwala tylko cechy różnicy, odrzucając wszystko, co ogólne, to, co zdaniem Studyty przemienia Pawła i Piotra w człowieka w ogóle. $Z$ drugiej strony mechanizm mimetyczny jest całkowicie osłabiony przez to, że ta mapa czystych różnic jest rzutowana na szkic, początkowo niebędący w żadnej relacji do modelu. Gogol tworzy eksperymentalną sytuację na granicy klasycznej reprezentacji. Na portrecie przedstawione jest nie oblicze nieobecnej persony, lecz mapa syngularności różnicy, odseparowana od tej persony, by tak rzec, hipostazowość, rzutowana na inne oblicze. Ta całkowicie niezwykła sytuacja pozwala Gogolowi wyjść poza ramy klasycznej reprezentacji.

Tę samą metodę twórczą wykorzystał w Portrecie również pewien malarz, który przysłał z Włoch swoje płótno do Akademii Sztuk. Płótno to studiuje, wstrząśnięty nim, Czartkow, który już dawno roztrwonił swój talent. Epizod ten w drugiej wersji opowieści został znacznie pełniej przedstawiony i z większym rozumieniem strony estetycznej. Tak oto, jeśli w wariancie Arabesek na tym „arcypłótnie” „wyjątkowo piękne figury pogrupowano niewymuszenie, swobodnie"75, to w późniejszej wersji wszelka aluzja do grupy jako nosicieli ogólnego obrazu jest usunięta, natomiast w pełni odtworzony został schemat portretu Lizy:

Wszystko zdawało się tutaj harmonijnie łączyć: głębokie wniknięcie w kunszt Rafaela odzwierciedlone szlachetnej kompozycji, wpływ Corregia widoczny w najwyższej doskonałości techniki. Ale najbardziej władczo występowała twórcza potęga, zawarta w duszy samego malarza. Przepoiła sobą każdy przedmiot w obrazie, wykryła prawa, które nimi rządzą, i ich wewnętrzną moc. Wszędzie była uchwycona ta płynna okrągłość linii zawarta w naturze, którą widzi tylko oko malarza-twórcy, a która tak kanciasto wychodzi u kopistów. Widać było, jak wszystko, co wydarł zewnętrznemu światu, malarz przenosił najpierw do własnej duszy, by dopiero stamtąd, z jej źródła, wytrysnęło harmonijną, tryumfalną pieśnią. Nawet dla niewtajemniczonych stało się jasne, jaka niezamierzona przepaść dzieli twórczość od zwykłego kopiowania natury. Niepodobna było wyrazić tego niezwykłego skupienia w oczach widzów wpatrzonych w obraz - żaden szelest, żaden dźwięk nie naruszał ciszy; obraz zaś zdawał się tymczasem wyrastać coraz wyżej, wyżej; jaśniej i cudowniej oddzielał się od wszystkiego, aż stał się wreszcie tylko chwilą, owocem myśli spadającej na artystę z niebios, chwilą, do której całe życie człowieka jest tylko wstępem. Mi-

75 Н.В. Гоголь, Собрание сочинений..., t. 3, s. 216. 
mowolne łzy gotowe były trysnąć z oczu widzów otaczających obraz. Zdawało się, że wszystkie upodobania, wszystkie zuchwałe, błędne odchylenia smaku zlały się w jeden hymn uwielbienia dla boskiego dzieła. Nieruchomo, $\mathrm{z}$ otwartymi ustami stał Czartkow przed obrazem ${ }^{76}$.

Gogol zdecydowanie przeciwstawia to płótno kopii. Płótno jest niemimetyczne. Antymimetyczność wyraża się przede wszystkim w śpiewności i okrągłości linii. Linie te odznaczają się tą swobodną dynamiką, jaka jest niemożliwa w kopiowaniu, ale jest możliwa jedynie w ruchu różnicy z wnętrza duszy samego artysty. Autor „arcypłótna" rzutuje ten wolny ruch na wzorce Rafaela i Correggia, ale bez kopiowania tych ostatnich.

Jest to właśnie ta projekcja czystej różnicy, „którą widzi tylko oko malarza-twórcy, a która tak kanciasto wychodzi u kopistów”. „Kanciastość kopistów” to brak dynamiki. W rezultacie powstaje takie płótno, które jest ideałem dla Gogola i, najprawdopodobniej, dla Iwanowa. Obraz wywiera ten oszałamiający efekt, który Gogol wiąże z modelem czystej hipostazowości, efektem niematerialnej syngularności. Obraz tak wstrząsa Czartkowem, jak powinny wstrząsnąć czytelnikiem Rewizor i Martwe dusze. Stąd się bierze też dziwna niema scena, w której bohater Gogola stoi nieruchomo z „otwartymi ustami”: „płacz i szlochanie wydarły mu się z piersi i jak oszalały wybiegł z sali”77.

Zaś sam Czartkow wybiera dla siebie inną drogę i staje się modnym portrecistą, czyli specjalistą w gatunku mimesis. Im więcej portretów maluje Czartkow, tym bardziej stają się one monotonne i podobne do siebie, aż w końcu są odbiciem jego własnego Ja lub odbiciem „człowieka w ogóle” w kategoriach Studyty. Różnica pomiędzy Ja i „człowiekiem w ogóle” przy tym praktycznie znika:

Pędzel jego stygł, tępiał i niepostrzeżenie zamknął się w monotonnych, określonych, wyświechtanych formach. Jednostajne, zimne, zawsze uporządkowane i, jeśli można tak rzec, zapięte na wszystkie guziki twarze urzędników, wojskowych i cywilnych, niewiele dawały pola do wykazania talentu: zapomniał o wspaniałym udrapowaniu, mocnym ruchu i namiętności. Tym bardziej nie było mowy o grupach, o artystycznie malarsko ujętym dramacie, o wzniosłym pomyśle; wciąż miał przed oczami tylko mundur, gorset lub frak, które ostudzają artystę i niweczą wszelką wyobraźnię ${ }^{78}$.

Portrety stają się coraz mniej podobne do oryginału, człowiek Piotr lub Paweł przemienia się po prostu w mundur, gorset lub frak. Ta utrata różnicy w gatunku mimetycznym Gogol wprost wiąże z komercyjnym charakterem tych prac, z tymi pieniędzmi, które przenikają do życia Czartkowa razem z portretem demonicznego lichwiarza. Pieniądze są, naturalnie, tym najbardziej oczywistym ekwiwalentem, wygładzającym wszystkie różnice. Ale Gogol przy tym wyraźnie wyczuwa związek jednostajności, wytwarzanej przez pieniądze, z tematem kopiowania, imitacji, zniknięcia syngularności oryginału.

W tej masowej jednostajności obrazów, przybierających postać prawdziwej fantasmagorii, renesansowa reprezentacja zyskuje ostateczne i paradoksalne zwieńczenie. Jeżeli w epoce odrodzenia wizjonerstwo miało oderwać sztukę od rzemiosła i nadać

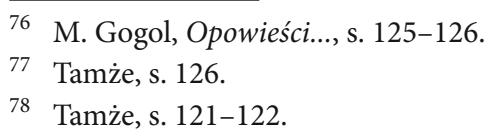


jej wysoki status społeczny, to, łącząc się z rynkową fantasmagorią, zwraca się ona jakby wstecz i znowu wchodzi w dziedzinę produkcji, co prawda, tym razem masowej. W okresie Quattrocento wizjonerska reprezentacja już miała za zadanie maskowanie materialnego aspektu pracy, przykrywając go czystą idealnością. Ale ta właściwość, która wydawała się w tamtym momencie wtórna, teraz wysuwa się na pierwszy plan w kontekście masowej produkcji towarowej, wypierającej materialny charakter pracy abstrakcyjnym pojęciem wartości. Wyobraźnia renesansowa wieńczy swoją historię rynkowymi fantasmagoriami XX wieku. Znamienne, że u Czartkowa odzież stopniowo zastępuje ludzi, a jego portrety stają się swego rodzaju witryną domu towarowego. „Wciąż miał przed oczami tylko mundur, gorset lub frak”. Sztuka staje się doskonałym analogonem witryn sklepowych, gdzie wystawiony towar jest ukazany w reżymie czystej reprezentacji i bynajmniej nie po to, aby go kupiono. Jak zauważa w związku z koncepcją fantasmagorii Benjamina Susan Buck-Morss, „wszystko pożądane, od seksu po status społeczny, może być przemienione w fetysz (fetish-on-display), trzymający tłum w stanie pobudzenia, nawet wówczas, kiedy nie jest on w stanie nabyć go. Rzeczywiście, niebotycznie wysoka cena tylko podkreśla symboliczną wartość towaru"79. Giorgio Agamben mówi w związku z tym o „towarze absolutnym”. W takim towarze zbiega się wartość użytkowa i wymienna. A to oznacza, że taki towar całkowicie traci wszelką użyteczność. Wartość takiego towaru wyraża się w jego nieużyteczności i nieuchwytności. Absolutny towar zdaniem Agambena jest towarem, w którym zburzony został wymiar towaru. I jest nim sztuka. W sytuacji rynku przeżycie sztuki zależy od przemienienia sztuki $\mathrm{w}$ „,absolutny towar" ${ }^{80}$. Nienawiść Czartkowa do arcydzieła, przysłanego z Włoch, być może wiąże się z tym, że on, jako człowiek rynku, poczuł w płótnie, które nim wstrząsnęło, zjawisko „towaru absolutnego”.

Śmierć Czartkowa jest spowodowana nieskończonym rozmnożeniem się portretów, które powodują u niego pomieszanie zmysłów. Malarz jakby znika we własnych dziełach, gdyż każdy portret jest tylko kopią jego samego, w której całkowicie rozpuszcza się jak w anonimowym towarze. Szaleństwo umierającego Czartkowa jest szaleństwem imitatora, szaleństwem reprezentacji, nad którą kontrola została utracona i która opanowuje świat, odcięty całkowicie od oryginałów:

Wszyscy, którzy otaczali jego łoże, wydawali mu się okropnymi portretami. Dwoiły się, mnożyły mu się w oczach; widział je na wszystkich ścianach, wpatrywały się w niego uporczywie żywymi oczami. Straszne portrety spoglądały z sufitu, z podłogi, pokój poszerzał się i wydłużał w nieskończoność, żeby móc jeszcze więcej zmieścić tych nieruchomych oczu ${ }^{81}$.

Antychryst przenika do świata jako imitacja Chrystusa i dlatego sztuka, którą niesie on ze sobą, nie jest hipostazową (czyli unikatową), ale mimetyczną, reprezentacyjną i w ostatecznym rachunku - rynkową. Jest rzeczą charakterystyczną, że Gogol kończy pierwszą część opowieści, ściślej - historię Czartkowa - obrazami wywróconego na opak ikonoklazmu. Jeśli autentyczny ikonoklazm niszczył ikony dlatego, że

79 S. Buck-Morss, Walter Benjamin and the Arcades Project, Cambridge, Mass. 1991, s. 82.

80 G. Agamben, Stanzas: Word and Phantasm in Western Culture. Transl. by R.L. Martinez, Minneapolis 1993, s. 42-43. Agamben w tym kontekście wspomina o Heglowskiej definicji doskonałości w poezji romantycznej jako „samolikwidacji nicości”.

81 M. Gogol, Opowieści..., s. 130. 
uważał je za puste obrazy, czystą imitację, to Czartkow (nowe ucieleśnienie imitatora Antychrysta) niszczy wszystkie te obrazy, które rzucają wyzwanie mimetyzmowi. Artysta-imitator skupuje na aukcjach i niszczy mnóstwo „świętych, wspaniałych dzieł, w których wielka sztuka uchyliła zasłonę z nieba i ukazała człowiekowi część przepełnionego dźwiękami i świętymi tajemnicami jego świata wewnętrznego" ${ }^{\text {"2. }}$.

W drugiej części opowieści przedstawia się historię stworzenia portretu lichwiarza przez ojca narratora, który przeżywa swoją pracę jako służbę szatanowi. Twórca portretu w końcu musiał pójść do klasztoru i oczyszczać modlitwami swoją duszę̨, dopóki na niego nie zstąpi pokój i pogoda ducha. W klasztorze spotyka swojego ojca narrator, sam wychowanek Akademii Sztuk. Ojciec przekazuje synowi takie „słowa i myśli (...) o sztuce, które, przyznam się, długo zachowam w duszy, i pragnąłbym szczerze, aby każdy z moich kolegów uczynił to samo" ${ }^{84}$. Jest jasne, że Gogol nadaje temu manifestowi prawdziwej sztuki prawie sakralne znaczenie. Ciekawe jednak, że w testamencie mnicha istnieją zasadnicze różnice pomiędzy pierwszym i drugim wariantem. W wariancie z Arabesek oczyszczenie poprzez modlitwę i przezwyciężenie mimetyzmu prowadzi do totalnego oderwania malarstwa od rzeczywistości: „Cały przemienił się w religijny płomień. Jego głowa wiecznie jest wypełniona cudownymi snami. Widzi na każdym kroku wizje i słyszy objawienia; myśli jego są rozpalone; oko już nie dostrzega niczego, co należy do ziemi (...)" ${ }^{35}$. Porzucenie imitacji prowadzi w pierwszym wariancie wprost do wizjonerstwa, które legenda przypisywała Rafaelowi.

W wariancie z 1842 roku odmowa kopiowania przybiera całkowicie inny, paradoksalny obrót. Tutaj mnich nawołuje do skrupulatnego kopiowania natury:

Wszystko zbadaj, cokolwiek tylko zobaczysz, opanuj wszystkie rodzaje malarstwa, ale wszędzie umiej znaleźć myśl wewnętrzną, przede wszystkim zaś staraj się zgłębić wzniosłą tajemnicę tworzenia. Błogosławiony jest wybraniec, który nią zawładnął. Nie istnieją dlań w przyrodzie rzeczy niegodne uwagi. W rzeczach błahych malarz-twórca jest tak samo wielki, jak w rzeczach wielkich; gdy przedstawia rzeczy pogardzane, przestajemy gardzić nimi, albowiem niewidzialne prześwieca przez nią piękna dusza tworzącego i oto rzecz pogardzana otrzymała wyraz wzniosły, gdyż przesączyła się już przez czyściec jego duszy ${ }^{86}$.

Przełożył Bogusław Żyłko

\section{Bibliografia / References}

Agamben, G. (1993). Stanzas. Word and Phantasm in Western Culture. Transl. by R.L. Martinez. Minneapolis: University of Minnesota Press.

82 Н.В. Гоголь, Собрание сочинений..., t. 3, s. 264. Cytuję wariant Arabesek.

83 Najprawdopodobniej Gogol projektuje na artystę swoje własne dążenia. Czyżewski pisał: „Gogol nazywa siebie nie tylko pielgrzymem, ale i «mnichem»: mówi o swoim «wewnętrznym klasztorze», żyje „jak w klasztorze” - miejsca, w których znajduje się jego, by tak rzec, wędrowny, ruchomy klasztor, są czasami nieco dziwne: na przykład, Paryż...” (Д. Чижевский, Неизвестньий Гоголь. W: Трудный путь: Зарубежная Россия и Гоголь, Москва 2002, s. 198).

84 M. Gogol, Opowieści..., s. 152.

85 Н.В. Гоголь, Собрание сочинений..., t. 3, s. 281.

86 M. Gogol, Opowieści..., s. 152. 
Alberti, L.B. (1966). On Painting. New Haven: Yale University Press.

Alpers, S. (1988). Rembrandt's Enterprise. Chicago: University of Chicago Press.

Apokrifičeskie Apokalipsisy (2001). Sankt-Peterburg: Aletejâ [Апокрифические Апокалипсисы (2001). Санкт-Петербург: Алетейя].

Auerbach, E. (1959). "Figura”. In: Auerbach, E. Scenes from the Drama of European Literature: Six Essays. New York: Meridian Books.

Barash, M. (1995). Icon. Studies in the History of an Idea. New York: New York University Press.

Barbu, D. (1996). L'image byzantine: production et usages. Annales HSS, 51: 71-92.

Belting, H. (2010). Obraz i kult: Historia obrazu przed epoką sztuki. Przeł. T. Zatorski, Gdańsk: Słowo/ Obraz terytoria.

Bezanson, A. (1999). Zapretnyj obraz: Intellektual'naâ istoriâ ikonoborčestva. Per. s fr. M. Rozanova. Moskva: МІК [Безансон, А. (1999). Запретный образ: Интеллектуальная история иконоборчества. Пер. с фр. М. Розанова. Москва: МИК].

Blanchot, M. (1997). Friendship. Transl. by E. Rottenberg. Stanford: Stanford University Press.

Brown, N.O. (1991). Apocalypse and/or Metamorphosis. Berkeley: University of California Press.

Buck-Morss, S. (1991). Walter Benjamin and the Arcades Project. Cambridge, Mass.: MIT Press.

Corbin, H. (1971). En Islam Iranien. Sohrawardî et les Platoniciens de Perse. Vol. 2. Paris: Gallimard.

Corbin, H. (1969). Creative Imagination in the Sufism of Ibn Arabi. Transl. by R. Manheim, Princeton: Princeton Legacy Library.

Cornack, R. (1997). Painting the Soul: Icons, Death Masks and Shrouds (Essays in Art and Culture). London: Reaktion Books.

Čiževskij, D. (2002). Neizvestnyj Gogol’. V: Trudnyj put': Zarubežnaâ Rossiâ i Gogol'. Sost., vstup. statâ i komment. M.D. Filina. Moskva: Russkij Mir”: 188-230 [Чижевский, Д. (2002). Неизвестный Гоголь. В: Трудный путь: Зарубежная Россия и Гоголь. Сост., вступ. статья и коммент. М.Д. Филина. Москва: Русскій Міръ: 188-230].

Damaskin, Ioann Sv. (2001). Tri slova v zaŝitu ikonopočitaniâ. Sankt-Peterburg: Azbuka-klassika [Дамаскин, Иоанн Св. (2001). Три слова в защиту иконопочитания. Санкт-Петербург: Азбука-классика].

Danilevskij, R.Û. (1986). Zametki o temah zapadnoevropejskoj živopisi v russkoj literature. V: Russkâ̂ literatura i zarubežnoe iskusstvo. Leningrad: Nauka [Данилевский, Р.Ю. (1986). Заметки о темах западноевропейской живописи в русской литературе. В: Русская литература и зарубежное искусство. Ленинград: Наука: 268-298].

Delille J. (1824). Oeuvres de J. Delille. T. 8-9: L'imagination II. Paris: L.G. Michaud.

Dionysius, the Areopagite (1940). On the Divine Names and the Mystical Theology. New edition. London-New York: Society for Promoting Christian Knowledge; Macmillan Co.

Florenskij, P.A. (1990). U vodorazdelov mysli. Т. 2. Moskva: Pravda [Флоренский, П.А. (1990). У водоразделов мысли. Т. 2. Москва: Правда].

Gabričevskij, A.G. (2002). Morfologiâ iskusstva. Moskva: Agraf [Габричевский, А.Г. (2002). Морботогия искусства. Москва: Аграф].

Gogol', N.V. (1953). Sobranie sočinenij. T. 3. Moskva: Goslitizdat [Гоголь, Н.В. (1953). Собрание сочинений. Т. 3. Москва: Гослитиздат].

Gogol, M. (1972). Opowieści. Przeł. J. Wyszomirski, J. Tuwim, J. Brzęczkowski. Oprac. B. Galster. Wrocław: Zakład Narodowy im. Ossolińskich.

Hamburger, J.F. (1998). The Visual and the Visionary. Art and Female Spirituality in Late Medieval Germany, New York: Princeton University Press.

Havelange, C. (1998). De l'oeil et $d u$ monde, une histoire du regard au seuil de la modernité. Paris: Fayard.

Hoffmann, E.T.A. (1958). Diable eliksiry. Przeł. L. Emirowicz. Warszawa: Czytelnik. 
Didi-Huberman, G. (1987). The Index of the Absent Wound (Monograph on a Stain). In: Michelson, A. et al. (Ed.). October: The First Decade. Cambridge, Mass.: The MIT Press: 39-57.

Inge, W.R. (1956). Christian Mysticism. New York: Meridian Books.

Krell, D.F. (1990). Of Memory, Reminiscence, and Writing on the Verge. Bloomington: Indiana University Press.

Kuryluk, E. (1991). Veronica and her cloth: history, symbolism, and structure of a „true" image. Cambridge-Oxford: Basil Blackwell.

Marin, L. (1977a). Détruire la peinture. Paris: Éditions Galilée.

Marin, L. (1977b). Philippe de Champaigne ou la présence cachée. Paris: Hazan.

Nancy, J.-L. (2000). Le Regard du portrait. Paris: Éditions Galilée.

Palama, Sv. Grigorij (1995). Triady v zaŝitusvâsenno-bezmolvstvuûsih. Per. na rus. âzyk V. Veniaminovym. Moskva: Kanon [Палама, Св. Григорий (1995). Триады в защиту священно-безмолвствующих. Пер. на рус. язык В. Вениаминовым. Москва: Канон].

Peter, The Acts of. (1993). In: Elliot, J.K. (Ed.). The Apocryphal New Testament: a collection of apocryphal Christian literature in an English translation. Oxford-New York: Oxford University Press; Clarendon Press.

Plotin (1995). Sočineniâ. Sankt-Peterburg: pri učastii Greko-latinskogo kabineta Û.A. Šičalina Moskva [Плотин (1995). Сочинения. Санкт-Петербург: при участии Греко-латинского кабинета Ю.А. Шичалина Москва].

Poirée, M.Ch. (1997). L'empreinte Au XXe siècle: De la Vèronique au „Verre ironique”. Paris: L'Harmattan.

Pulver, M. (1960). The experience of Light in the Gospel of St. John, in the „Corpus hermeticum”, in Gnosticism, and in the Eastern Church. In: Campbell, J. (Ed.). Spiritual Disciplines. Papers from the Eranos Yearbooks 4. Princeton, N.Y.: Princeton University Press: 239-266.

Schleiermacher, F. et al. (1963). The Christian Faith. Vol. 1. New York-Evanston: Harper \& Row.

Simmel, G. (2005). Rembrandt: An Essay in the Philosophy of Art. Transl and ed. by A. Scott, H. Staubmann. New York: Routledge.

Studit, Feodor (1987). Tret'e oproverženie ikonoborcev. Simvol 18 (Pariž): 295-332 [Студит, Феодор (1987). Третье опровержение иконоборцев. Символ 18 (Париж): 295-332].

Studit, Feodor (1987). Poslanie Platonu opočitanii ikon. Pervoe oproverženie ikonoborcev. Vtoroe oproverženie ikonoborcev. Tret'e oproverženie ikonoborcev. Simvol 18 (Pariž): 249-252 [Студит, Феодор (1987). Послание Платону о почитании икон. Первое опровержение иконоборцев. Второе опровержение иконоборцев. Третье опровержение иконоборцев. Символ, 18 (Париж): 249-252].

Tertullian (1994). Izbrannye prozivedeniâ. Per. s lat., red. i sost. A.A. Ctolârova. Moskva: Progress; Kul'tura [Тертуллиан (1994). Избранные прозиведения. Пер. с лат., ред. и сост. А.А. Столярова. Москва: Прогресс; Культура].

Turčin, V.S. (1981). Ėpoha romantizma v Rossii. Moskva: Iskusstvo [Турчин, B.C. (1981). Эпоха романтизма в России. Москва: Искусство].

Vajskopf, M. (2002). Sûžet Gogolâ. Moskva: Rossijskij gosudarstvennyj gumanitarnyj universitet [Вайскопф, М. (2002). Сюжет Гоголя. Москва: Российский государственный гуманитарный университет].

Vajskopf, М. (2003). Nos v kazanskom sobore: o genezise religioznoj temy. V: Vajskopf, М. Прuцатройка и колеснииа души. Raboty 1978-2003 godov. Москва: Novoe literaturnoe obozrenie [Вайскопф, М. (2003). Нос в казанском соборе: о генезисе религиозной темы. В: Вайскопф, М. Прииа-тройка и колесница души. Работы 1978-2003 годов. Москва: Новое литературное обозрение].

Valery, P. (1960). Tel Quel. In: P. Valery, Oeuvres. T. 2. Paris: Gallimard. 
Zendler, E. (1987). Genezis i bogoslovie ikony. Simvol, 18 (Pariž): 13-54 [Зендлер, Э. (1987). Генезис и богословие иконы. Символ, 18 (Париж): 13-54].

Živov, V.M. (2002). Bogoslovie ikony v pervyj period ikonoborčeskih sporov. V: Živov, V.M. Razyskaniâ $v$ oblasti istorii i predystorii russkoj kul'tury. Moskva: Âzyki slavânskoj kul'tury [Живов, В.М. (2002). Богословие иконы в первый период иконоборческих споров. В: Живов, В.М. Разыскания в области истории и предыстории русской культуры. Москва: Языки славянской культуры].

Žukovskij, V.A. (1985). Rafaeleva "Madonna". V: Žukovskij, V.A. Ėstetika i kritika. Moskva: Isskustvo [Жуковский, В.А. (1985). Rафаелева “Мадонна". В: Жуковский, В.А. Эстетика и критика. Москва: Исскуство].

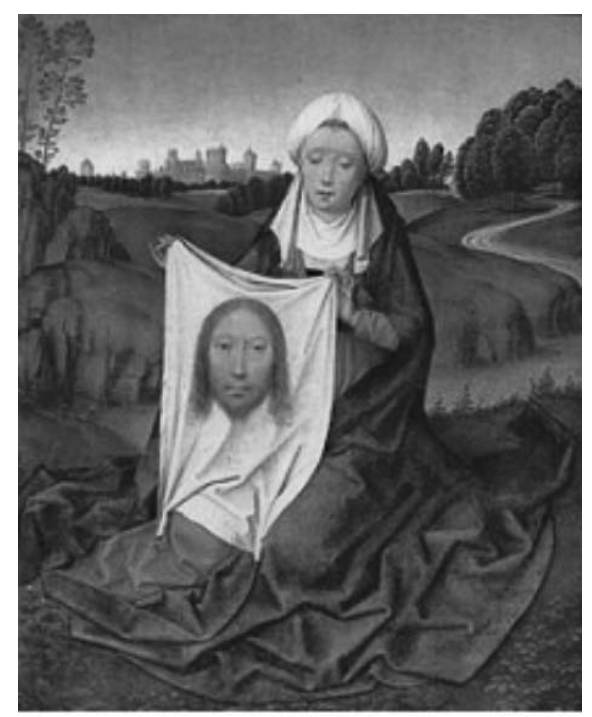

Il. 1. Hans Memling, Chusta św. Weroniki (chusta z Manoppello) (1470) Źródło: pl.wikipedia.org (domena publiczna)

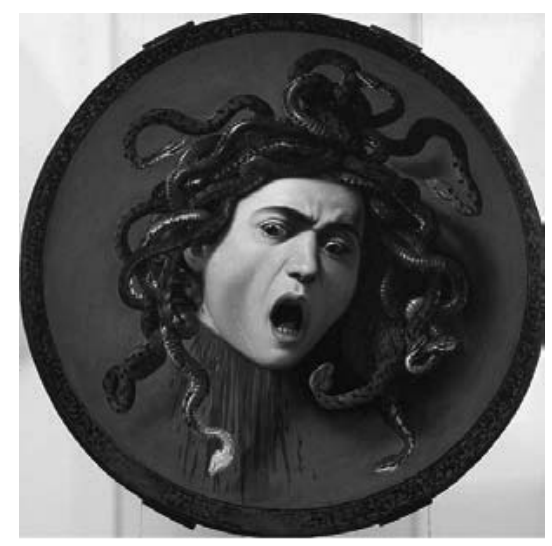

Il. 2. Caravaggio, Głowa Meduzy (ca. 1596)

Źródło: pl.wikipedia.org (domena publiczna) 


\section{Nota o Autorze}

Michaił Jampolski - urodził się w Moskwie w 1949 roku. Ukończył filologię germano-romańską na Uniwersytecie Moskiewskim. W 1977 roku obronił pracę doktorską Образовательные и воспитательные функиии курса филсофии в средней иколе Франиии. Od 1974 roku związany zawodowo z Wszechzwiązkowym Instytutem Naukowo-Badawczym Sztuki Filmowej. Publikuje w serii semiotycznej Uniwersytetu Tartuskiego i uczestniczy w Konferencjach Tynianowowskiej w Rzeczycy na Łotwie. W 1991 roku habilitował się w Instytucie Sztuki Filmowej na podstawie rozprawy Проблема интертекстуальности в кинематограбе. W latach 1991-1992 przenosi się do Instytutu Filozofii Rosyjskiej Akademii Nauk i zostaje współpracownikiem postmodernistycznego filozofa Walerija Podorogi. Od 1992 roku jest profesorem Uniwersytetu Nowojorskiego. Opublikował ponad 20 książek z zakresu filmoznawstwa, semiotyki kultury, historii reprezentacji i fenomenologii obrazu. Najważniejsze $\mathrm{z}$ nich to: Память Тиресия. Интертекстуальность и кинематограф (1993), Демон и лабиринт. Диаграммь, деформачии, мимесис (1996), Наблюдатель. Очерки истории видения (2000, 2012), Язык - тело - случай. Кинематограб и поиски смысла (2004), Пространственная история. Три текста об истории (2013), Без будущего. Культура и время (2018), Изображение. Курс текиий (2019). Prace Michaiła Jampolskiego pojawiały się już w tłumaczeniu na język polski. Jedną z pierwszych był artykuł Dialog i struktura przestrzeni filmowej (O rewersyjnych modelach montażowych), opublikowany w antologii Cudowny kinemo. Rosyjska myśl filmowa (Wybór, przekłady i opracowanie: T. Szczepański i B. Żyłko, Gdańsk: Słowo/obraz terytoria, 2001).

\section{Od Tłumacza}

Książka Ткач и визионер. Очерки истории репрезентаиии, или О материальном и идеальном в культуре (Moskwa 2007) jest, jak wskazuje jej tytul, fragmentaryczną historią reprezentacji w kulturze i sztuce europejskiej. Pojęcie reprezentacji jest niedawnej proweniencji, które w ostatnich paru dekadach zrobiło wielką karierę, zastępując wcześniej używany termin „przedstawienie”, wywodzący się z Arystotelesowskiej kategorii mimesis, rozumianej jako „naśladowcze przedstawienie rzeczywistości” w literaturze i sztuce. U Michaiła Jampolskiego to kluczowe pojęcie jest określane następująco:

Klasyczna reprezentacja to szczególna forma przedstawienia rzeczywistości. Jest ona ufundowana na zastąpieniu pewnego obiektu jego iluzorycznym obrazem. Nieobecność przedstawianego obiektu zastępuje się w niej iluzją obecności. Przy tym iluzja nigdy nie osiąga takiej intensywności, żeby dosłownie oszukać widza lub czytelnika. Iluzja prawie zawsze nie ukrywa tego, że nie posiada prawdziwego bytu. (...) Reprezentacja lokuje się pomiędzy realnością i światem idei platońskich. Dlatego jej sferą jest wyobraźnia.

Zdaniem autora idea reprezentacji pojawia się $\mathrm{w}$ okresie odrodzenia, kiedy to akcent przenosi się ze sztuki, rozumianej jako techne, na osobę artysty obdarzonego wyjątkowymi zdolnościami „widzenia” przedmiotów wewnętrznym okiem wyobraźni. 
Tej problematyce poświęcona jest pierwsza część książki. Bohaterem drugiej części książki jest miasto i jego reprezentacje, przy czym uwaga autora skupia się na Petersburgu, tym wyjątkowym mieście w historii Rosji w przeciwstawieniu do innego wyjątkowego miasta, jakim jest Rzym - Roma aeterna. Trzecia część traktuje o portrecie i ikonie z nawiązaniem do prawosławnej teologii ikony i jej roli w duchowej kulturze rosyjskiej. Ikona z jej poetyką jest stałym punktem odniesienia w krytyce "świeckiego" wizjonerstwa. Publikowany w tym numerze fragment pochodzi z tej ostatniej części, gdzie stanowi jej centrum.

\title{
BOGUSŁAW ŻYŁKO
}

\author{
Akademia Humanistyczno-Ekonomiczna w Łodzi / \\ University of Humanities and Economics in Lodz \\ Wydział Humanistyczny / Faculty of Humanities \\ Katedra Literaturoznawstwa / Department of Literary Studies \\ ul. Sterlinga 26, 90-212 Łódź, Polska / Sterlinga 26 St., 90-212 Łódź, Poland \\ ORCID: https://orcid.org/0000-0003-4605-0719 \\ (Nadesłano / Received 20.09.2020. Zaakceptowano / Accepted 18.10.2020)
}

Competing interests: The translator declares that he has no competing interests. 